\title{
Formation of ferroan dacite by lunar silicic volcanism recorded in a meteorite from the Moon
}

\author{
Hiroshi Nagaoka ${ }^{1,2^{*}} \mathbb{D}$, Timothy J. Fagan ${ }^{3}$, Masahiro Kayama ${ }^{4,5,6}$, Yuzuru Karouji ${ }^{7}$, Nobuyuki Hasebe ${ }^{1,8}$ and \\ Mitsuru Ebihara ${ }^{3}$
}

\begin{abstract}
An igneous clast from the Northwest Africa 773 (NWA 773) clan of lunar meteorites formed by silicic volcanism on the Moon. The clast was identified in Northwest Africa 2727 (NWA 2727), which is included in the NWA 773 clan. Over 80 mode\% of the clast consists of silica + plagioclase + K-Ba-feldspar. The silica phases cristobalite, tridymite, and quartz are all present in the clast, indicating rapid cooling at low pressure in agreement with a volcanic setting. This clast is characterized as a dacite on the basis of mineral modes and whole-rock chemical composition. Olivine and pyroxene in the clast have high Fe/Mg ratios (olivine Fe\# > 99, pyroxene Fe\# > 99; with Fe\# = molar Fe/(Fe + $\mathrm{Mg} \times \times 100$ ), suggesting crystallization from a residual liquid after fractionation of more magnesian silicates. The clast is similar in some respects to ferroan gabbro alkaline-phase-ferroan (FG/ARFe) clasts that are inferred to be comagmatic with olivine gabbro $(\mathrm{OG})$ and other mafic lithologies of the NWA $773 \mathrm{clan}$. However, the high silica concentration and dominance of apatite as the main Ca-phosphate (no merrillite was identified) are distinct from the FG/ARFe clasts. Thus, the dacite clast probably crystallized in a magmatic setting that was independent of the $\mathrm{OG}$ and FG/ARFe lithologies. The mafic major element composition, young age, and high KREEP-content of the NWA 773 clan have been used previously to infer an origin from the Procellarum-KREEP terrane (PKT) on the nearside of the Moon. Several candidates for silicic volcanism/plutonism have been identified in the PKT (e.g., Gruithuisen Domes, Hansteen alpha, Lassell Massif). The presence of the dacite lithology provides additional support for an origin in or around PKT for meteorites of the NWA 773 clan, and for complex igneous activity in PKT region.
\end{abstract}

Keywords: Moon, Mineralogy, Petrology, Volcanology, Silicic volcanism

\section{Introduction}

On Earth, igneous processes in diverse geochemical settings have resulted in wide compositional ranges of mafic to silicic rocks which form the crust. In contrast, the surface of the Moon is dominated by anorthositic rocks in the highlands and basaltic rocks in the lowlands. Anorthosites of the lunar highlands are interpreted as flotation cumulates from the lunar magma ocean (Warren 1985). Lunar basalts form by volcanic eruptions from the interior after partial melting in the mantle and are concentrated on the nearside of the

\footnotetext{
* Correspondence: hiroshi-nagaoka@asagi.waseda.jp

${ }^{1}$ Research Institute for Science and Engineering, Waseda University, 3-4-1 Okubo, Shinjuku, Tokyo 169-8555, Japan

${ }^{2}$ Institute of Space and Astronautical Science, Japan Aerospace Exploration Agency, 3-1-1 Yoshinodai, Chuo-ku, Sagamihara 252-5210, Japan

Full list of author information is available at the end of the article
}

Moon, in and near the Procellarum-KREEP Terrane (PKT, with KREEP indicating enrichment in $\mathrm{K}$, rare earth elements, and P) (Jolliff et al. 2000; Grove and Krawczynski 2009). Though the absolute age (or ages) of anorthosites in the highlands has been a topic of recent research (e.g., Borg et al. 2011; Barboni et al. 2017), it has been well established both from crater frequency counting and isotopic ages that basalts of the lunar lowlands (maria) are younger than the highlands anorthosites (e.g., Nyquist and Shih 1992; Hiesinger et al. 2003, 2010; Morota et al. 2011; Snape et al. 2016). For the most part, the anorthosites have crystallization ages prior to $4.3 \mathrm{Ga}$, whereas the main pulse of mare volcanism occurred from 3.9 to $3.2 \mathrm{Ga}$. Isotopic crystallization ages for a few lunar basalts are as young as 2.9-3.0 Ga (Borg et al. 2009; Elardo et al. 2014), and crater counts indicate that basaltic 
volcanism continued in the PKT to at least $1.5 \mathrm{Ga}$ (Hiesinger et al. 2003; Morota et al. 2011).

In contrast to basalts and anorthosites, granitic rocks are rare on the Moon, comprising well under $0.1 \%$ by mass of the Apollo collection as reported by Seddio et al. (2015). Nonetheless, the presence of granitic rocks is an indicator of compositional evolution by igneous processes in the Moon. Some candidates for localities where the lunar silicic rocks occur have been identified from remote sensing data sets that combine infrared spectroscopy, gamma-ray spectroscopy, and topography. Gruithuisen Domes, Hansteen alpha, and Lassell Massif have infrared spectra indicating silica-rich compositions (Glotch et al. 2010) and are located in the PKT, which as described above, has a long-term history of volcanism on the Moon. Gruithuisen domes and Hansteen alpha are topographic highs, indicating that they may have formed from rhyolitic volcanism, whereas intrusive granites may be exposed at Lassell and parts of Aristarchus crater (see Head and McCord 1978 and Hawke et al. 2003, in addition to Glotch et al. 2010).

Some of the processes that have been linked to the origin of silicic rocks on the Moon include (1) underplating of crust by basaltic magma and low-degree partial melting of crustal rocks (e.g., Hagerty et al. 2006; Glotch et al. 2010); (2) silicate liquid immiscibility resulting in co-existence of $\mathrm{FeO}$-rich mafic and $\mathrm{SiO}_{2}$-alkali-rich liquids (e.g., Rutherford et al. 1976; Fagan et al. 2014); and (3) fractional crystallization of basaltic liquid (e.g., Seddio et al. 2013). Similar processes play roles during granite formation on the Earth, but plate tectonics, terrestrial weathering and sedimentation, and high-water pressures in the crust have dramatic effects on formation of terrestrial granitic rocks (e.g., Tatsumi 2000; Weinberg and Hasalová 2015). In the case of Earth, granite formation is often associated with wet conditions during various stages of melting and crystallization (Campbell and Taylor 1983; Brown 2013). However, terrestrial Atype or ferroan granitoids are characterized by more anhydrous conditions (Frost and Frost 2011), and share some similarities in mineralogy, chemistry, and possibly origin with granitic rocks on differentiated bodies other than the Earth (Bonin 2012). Based on the andesitic meteorites Graves Nunatak 06128/9 (GRA 06128/9; Day et al. 2009), Northwest Africa 11119 (NWA 11119; Srinivasan et al. 2018), and trachyandesite ALM-A from the Almahata Sitta ureilite strewn field (Bischoff et al. 2014), it is known that silica-rich volcanism occurred in the early solar system, within a few million years of Ca-Alrich inclusions. From study of meteorites from asteroid 4 Vesta, dacite formation occurred on Vesta by crustal partial melting (Hahn Jr. et al. 2017). Therefore, silicic igneous rocks formed by conditions and processes distinct from the settings typical of Earth. Petrologic description of samples of lunar silicic rocks is an essential step toward evaluating the igneous processes that led to granite formation on the Moon and other celestial bodies.

Here, we have found a silicic clast in the lunar meteorite breccia Northwest Africa 2727 (NWA 2727), which is included in the NWA 773 clan of lunar meteorites (Jolliff et al. 2007; Nagaoka et al. 2019). NWA 773 clan meteorites share a distinctive olivine gabbro (OG) lithology (Fagan et al. 2003; Jolliff et al. 2003; Zhang et al. 2011; Valencia et al. 2019). In addition to the OG lithology, the NWA 773 clan contains a variety of basaltic clasts, feldspar + pyroxene gabbro, olivine-pyroxene-silica symplectites, and silica-bearing alkaline-phase-ferroan (ARFe) clasts. Several of these clast-types have been linked together to form during a common igneous differentiation suite (Fagan et al. 2014; Shaulis et al. 2017; Valencia et al. 2019). The likely parental material of the differentiation suite had a very low-Ti mafic and KREEP-bearing composition similar to green picritic glass from Apollo 14 site (Jolliff et al. 2003; Valencia et al. 2019). As discussed above, several candidates for silicic magmatism have been identified in the PKT (Glotch et al. 2010 and references therein). In this study, we describe the mineralogical and petrological characteristics of the silicic clast to constrain its origin. Furthermore, we compare the silicic clast with other silica-bearing lithic clasts of the NWA 773 clan and other lunar and terrestrial samples to consider implications of the clast for the origin of silica-bearing igneous rocks in general.

\section{Methods/Experimental}

\section{NWA 2727, a member of the NWA 773 clan of lunar meteorites}

Lunar meteorite NWA 2727 was found in Morocco or Algeria in 2005 (Connolly et al. 2006), and is a polymict, mafic breccia belonging to the NWA 773 clan (Bunch et al. 2006; Zeigler et al. 2007; Kayama et al. 2018; Valencia et al. 2019). As a whole, the NWA 773 clan consists of a coarsegrained regolith breccia with variable abundances of gabbroic and basaltic lithologies (Valencia et al. 2019). The gabbroic lithologies were roughly divided into three types (Fagan et al. 2003, 2014; Jolliff et al. 2003; Zhang et al. 2011; Valencia et al. 2019): olivine gabbro (OG, an olivine-pyroxeneplagioclase-rich rock); anorthositic gabbro (AG, a plagioclase-rich rock with some pyroxene); and ferroan gabbro (FG, a group of lithologies all having high Fe\# = molar $\mathrm{Fe} /[\mathrm{Fe}+\mathrm{Mg}]$; see below). OG clasts in NWA 773 clan have been well characterized by previous studies (Fagan et al. 2003; Jolliff et al. 2003; Zhang et al. 2011; Nagaoka et al. 2015; Valencia et al. 2019). Isotopic Sm-Nd isochron ages of the OG lithology have been analyzed by Borg et al. (2009), who reported an age of $2.99 \pm 0.03 \mathrm{Ga}$, and by Nyquist et al. (2009), reporting an age of $3.10 \pm 0.05 \mathrm{Ga}$. Isotopic analyses 
of baddeleyite crystals in the OG lithology and in other types of clasts yield $\mathrm{Pb}-\mathrm{Pb}$ ages near 3.1 Ga (Zhang et al. 2011; Shaulis et al. 2017). In contrast, a zircon crystal from the NWA 773 breccia has a U-Pb age of $3.958 \pm 0.018 \mathrm{Ga}$ (Shaulis et al. 2017). The AG lithology consists mostly of plagioclase and pyroxene. Anorthositic gabbro clasts have cumulate texture consisting of coarse crystals of anhedral plagioclase intergrown with pyroxene (Valencia et al. 2019). Although FG is variable in mineral assemblage, mineral zoning, and texture, the ferroan composition of mafic minerals is common in the FG lithology. The following ferroan lithologies are included in FG group (Valencia et al. 2019): pyroxene gabbro, symplectite clasts, and alkaline-phase-ferroan (ARFe) clasts (Fagan et al. 2003, 2014; Jolliff et al. 2003). The pyroxene gabbro is dominated by zoned pyroxene and usually contains plagioclase feldspar as well. Symplectite clasts consist of fine, curved intergrown fayalite, hedenbergite, and silica. Even though silica occurs as a characteristic phase of the symplectite lithology, the symplectite also contains fayalite and is not $\mathrm{SiO}_{2}$-rich in its bulk composition. Fayalite and silica also occur together in the ARFe lithology, but they form coarser crystals instead of symplectic intergrowths; in addition, the ARFe clasts contain K-Ba-feldspar and/or feldspathic glass along with merrillite, \pm apatite, \pm ilmenite, and \pm hedenbergitic pyroxene.

These three gabbros (OG, AG, FG) formed from a comagmatic sequence of crystallization (Fagan et al. 2014; Shaulis et al. 2017; Valencia et al. 2019). Furthermore, olivine phyric basalt (OPB) is a clast-type included in several NWA 773 clan meteorites, and is interpreted as co-magmatic with the three gabbros (Valencia et al. 2019). NWA 2727 includes clasts of all of the four lithologies described above (OG, AG, FG, OPB), as reported by Valencia et al. (2019).

In addition to the $\mathrm{OPB}$, other types of basaltic clasts with pyroxene phenocrysts have been found in the NWA 773 clan. Basalts with pyroxene phenocrysts in fine pyroxene+ feldspar groundmass occur in NWA 773 (Fagan et al. 2003, see their "straw-textured clast") and in NWA 2727 (Kayama et al. 2018). Anhedral quartz single crystals (10 to $20 \mu \mathrm{m}$ in radius) are present in clinopyroxene-phyric basalt (CPB) clasts in NWA 2727 (Kayama et al. 2018). The presence of multiple types of basalts indicates that some clasts of the NWA 773 clan formed initially from variable types of volcanism.

The NWA 773 clan shares (1) mafic minerals and major element composition; (2) isotopic ages of 3.0 to $3.1 \mathrm{Ga}$ for the most part, though some clasts in the breccia are older; and (3) KREEP-rich minor element composition (Fagan et al. 2003; Jolliff et al. 2003; Zhang et al. 2011; Valencia et al. 2019). On the basis of mafic composition, geochemical KREEP signature, and young crystallization age, NWA 773 clan is considered to originate from PKT (Jolliff et al. 2003).

\section{Analytical methods for mineralogy and petrology}

The polished thin section (PTS) of NWA 2727 was investigated by a combination of petrographic and chemical microanalyses including electron microprobe spectroscopy and scanning electron microscope imaging and mapping. Thin-section scale back-scattered electron (BSE) images and X-ray elemental maps were collected by an electron probe micro-analyzer (EPMA) (JEOL JXA-8900) at Kobe University. Clast-scale BSE images and X-ray elemental maps of the silicic clast were captured using the Hitachi S-3000 N scanning electron microscope (SEM) and JEOL JXA-8900 EPMA at Waseda University. These X-ray elemental images were adjusted and combined using an imaging analytical tool (Adobe Photoshop ${ }^{\circ}$ ). Photoshop was also used to estimate the area fraction (mode) of minerals from elemental maps covering approximately $3 \mathrm{~mm}^{2}$ in the silicic clast by counting pixels of each phase, which is taken to be proportional to the volume fraction. Mineral phases and modes were identified and determined based on the combined X-ray element maps.

Quantitative analyses of minerals in the silicic clast were performed by wavelength dispersive spectroscopy using a JEOL JXA-8900 EPMA at Waseda University with (1) an accelerating voltage of $15 \mathrm{kV}$ and a probe current of $2.0 \times 10^{-8} \mathrm{~A}$ for feldspar, silica, pyroxene, olivine, and Fe-oxide, and (2) $7 \mathrm{kV}$ and $2.0 \times 10^{-8} \mathrm{~A}$ for Caphosphate. Quantitative major element analyses were determined for the silicates and Fe-oxide; the main goal of the $\mathrm{Ca}$-phosphate analyses was to use $\mathrm{Ca} / \mathrm{P}$ ratios to distinguish apatite from merrillite. During electron irradiation using EPMA, alkali feldspar crystals showed blue cathodoluminescence that faded during exposure to the electron beam. Well-characterized oxides, silicates, and phosphates were used as standards. Approximate lower limits of detection for the $15 \mathrm{kV}$ analyses are as follows (in wt\%): $\mathrm{Na}_{2} \mathrm{O}=0.02 ; \mathrm{MgO}=0.02 ; \mathrm{Al}_{2} \mathrm{O}_{3}=0.03 ; \mathrm{SiO}_{2}=$ 0.04; $\mathrm{P}_{2} \mathrm{O}_{5}=0.03 ; \mathrm{K}_{2} \mathrm{O}=0.01 ; \mathrm{CaO}=0.02 ; \mathrm{TiO}_{2}=0.05$; $\mathrm{Cr}_{2} \mathrm{O}_{3}=0.04 ; \mathrm{MnO}=0.05 ; \mathrm{FeO}=0.06 ; \mathrm{BaO}=0.03$. Only data with analytical totals of $98-102 \mathrm{wt} \%$ with close fits to the mineral stoichiometries were selected in this paper.

Laser micro-Raman spectroscopy was carried out to identify minerals using Thermo Electron (Nicolet Almega $\mathrm{XR}$ ) with the $532 \mathrm{~nm}$ excitation line of the Nd:YAG laser at Okayama University of Science. The source laser power was set at $20 \mathrm{~mW}$ on the sample with a $\sim 2 \mu \mathrm{m}$ spot diameter. Raman spectra of minerals were collected with the wavenumber range from 150 to $800 \mathrm{~cm}^{-1}$ with step size of $1 \mathrm{~cm}^{-1}$. Raman intensity mapping was measured along the $\mathrm{X}$ and $\mathrm{Y}$ directions with $30 \mu \mathrm{m}$ step sizes. In the Raman maps, the integral intensities of the main bands for each mineral were extracted from the spectral data of each measuring point to observe distributions of minerals. The Raman data were collected in five accumulations of $60 \mathrm{~s}$ 
for the spectra and three accumulations of $30 \mathrm{~s}$ exposure time for mapping. All the spectral data were calibrated by monitoring the position of the $\mathrm{O}-\mathrm{Si}-\mathrm{O}$ bending vibration $\left(464 \mathrm{~cm}^{-1}\right)$ in reference standard quartz of high optical grade before and after each measurement. Detailed information on the Raman spectroscopy is shown in Kayama et al. (2018).

\section{Results}

\section{Petrography}

Figure 1 shows false-color elemental mapping of $\mathrm{Al}$ (red), Mg (green), and Fe (blue) Ka x-rays, and distinguishes the main minerals of NWA 2727, as shown in the following colors: light green and blue colors indicate olivine; dark green and blue colors indicate pyroxene; red color indicates plagioclase. The PTS contains several types of clasts identified as mafic lithologies including OG, AG, FG (pyroxene gabbro), OPB, and the silicic clast (Fig. 1). The diversity of clast-types in our polished thin section (PTS) is consistent with previous work on NWA 2727, except for the silicic clast, which has not been described previously (Bunch et al. 2006; Zeigler et al. 2007; Valencia et al. 2019). Petrological descriptions of each lithology in the PTS are summarized below.

The OG lithology consists mostly of olivine and pyroxene with plagioclase. Large and small varieties of OG clasts are included in the PTS. The largest OG clast in this PTS is $8.0 \times 6.2 \mathrm{~mm}$ in size (Fig. 2a). Olivine (light green grains in Fig. 2a; $57 \mathrm{vol} \%$ ) is the most abundant mineral in this OG clast. Olivine occurs as subhedral to euhedral crystals ranging from $100 \mu \mathrm{m}$ up to $1.8 \mathrm{~mm}$ across. Several grains of olivine are over $1 \mathrm{~mm}$ across. Pyroxene (dark green grains in Fig. 2a; 25 vol\%) is the second most abundant mineral. Pyroxene crystals in the OG also are coarse, with grain sizes up to $1 \mathrm{~mm}$ across. Anhedral crystals of plagioclase (red in Fig. 2a; 16 vol\%) typically occur between coarse olivine and pyroxene. Plagioclase often appears elongate in the OG clast, with grain sizes up to $1.3 \times 0.3 \mathrm{~mm}$. Large olivine crystals with pyroxene and plagioclase filling interstices indicate the cumulate texture. Fe-oxides occur in trace abundances in the OG clast, and are located between coarse minerals. Silica minerals are not found in the OG clast. These petrological features are similar to other OG clasts in the NWA 773 clan (Fagan et al. 2003; Jolliff et al. 2003; Zhang et al. 2011; Nagaoka et al. 2015; Valencia et al. 2019).

The AG has a cumulate texture and is dominated by plagioclase and pyroxene (Valencia et al. 2019). One plagioclase-rich clast with texture similar to the AG was identified in the PTS. The clast is $4.4 \times 4.3 \mathrm{~mm}$ in size in this PTS (Fig. 2b). Plagioclase (red in Fig. 2b; 35 vol\%) occurs as elongate-appearing crystals, with grain sizes up to $2.1 \times 0.5 \mathrm{~mm}$. Plagioclase in the clast (35 vol\%) is more abundant than in the OG lithology (16 vol\%).
Pyroxene (dark green in Fig. 2b; 27 vol\%) forms elongate crystals between coarser plagioclase. Olivine (light blue in Fig. 2b; 36 vol\%) shows some euhedral crystal faces, with grain sizes ranging from 0.3 to $2 \mathrm{~mm}$ across. Silica minerals were not identified. The mineral assemblage of this clast is similar to that of the OG, but the mineral textures and modal abundances are different. Plagioclase in this clast is much more abundant than in OG clasts. This clast has coarse laths of anhedral plagioclase intergrown with pyroxene similar to the cumulate texture of AG as described by Valencia et al. (2019). Therefore, the plagioclase-rich clast is categorized as AG, although the presence of olivine was not reported in the AG clasts described by Valencia et al. (2019).

The FG group includes variable types of ferroan lithologies (described above; also see Fagan et al. 2014; Valencia et al. 2019). One clast of pyroxene gabbro (part of the FG group) in the PTS is approximately $7.8 \times 5.2 \mathrm{~mm}$ across in this PTS (Fig. 2c). The clast consists mostly of plagioclase and pyroxene, which are in subequal proportions. Plagioclase (red in Fig. 2c) occurs as both small and large crystals, ranging up to $1.6 \mathrm{~mm}$ across. The pyroxene crystals are up to $2.0 \mathrm{~mm}$ across and are zoned to Fe-rich compositions (from dark green to blue color in Fig. 2c), which are characteristic of the pyroxene gabbro lithology as defined by Fagan et al. (2014). No silica minerals were identified in the internal texture of this clast, although silica minerals (e.g., tridymite) were found along the boundary between the FG clast and the breccia matrix, and in veins that cut through the clast (Kayama et al. 2018). In addition to the large pyroxene gabbro clast, other FG lithologies are present as smaller clasts in the PTS and in other specimens of NWA 2727 (Bunch et al. 2006; Valencia et al. 2019).

One large basaltic clast, covering an area of $5.6 \times$ $3.6 \mathrm{~mm}$ is present in the PTS (Fig. 2d). Olivine phenocrysts (light blue in Fig. 2d) are surrounded by a finegrained groundmass of pyroxene (dark blue in Fig. 2d) and plagioclase (red in Fig. 2d). The grain sizes of olivine phenocrysts are from $0.3 \times 0.1 \mathrm{~mm}$ to $0.6 \times 0.3 \mathrm{~mm}$ across. The presence of olivine phenocrysts and finegrained groundmass consisting of pyroxene and plagioclase of this basaltic clast are similar to the olivinephyric basalt (OPB) described by Valencia et al. (2019).

Plane-polarized light, BSE, and elemental RGB images of the silicic clast are presented in Fig. 3. The silicic clast consists mostly of plagioclase, alkali feldspar, and silica, which comprise $>80$ vol\% of the mode as exposed in our PTS (Table 1; Fig. 3). The silicic clast is $2.2 \times 1.3 \mathrm{~mm}$ in size in this PTS. Olivine and high-Ca pyroxene also occur in the clast, and $\mathrm{Ca}-$ phosphate, ilmenite, chromite, and troilite are present as minor minerals. All of the Ca-phosphate analyzed here by EPMA yielded apatite stoichiometry; merrillite was not identified. 


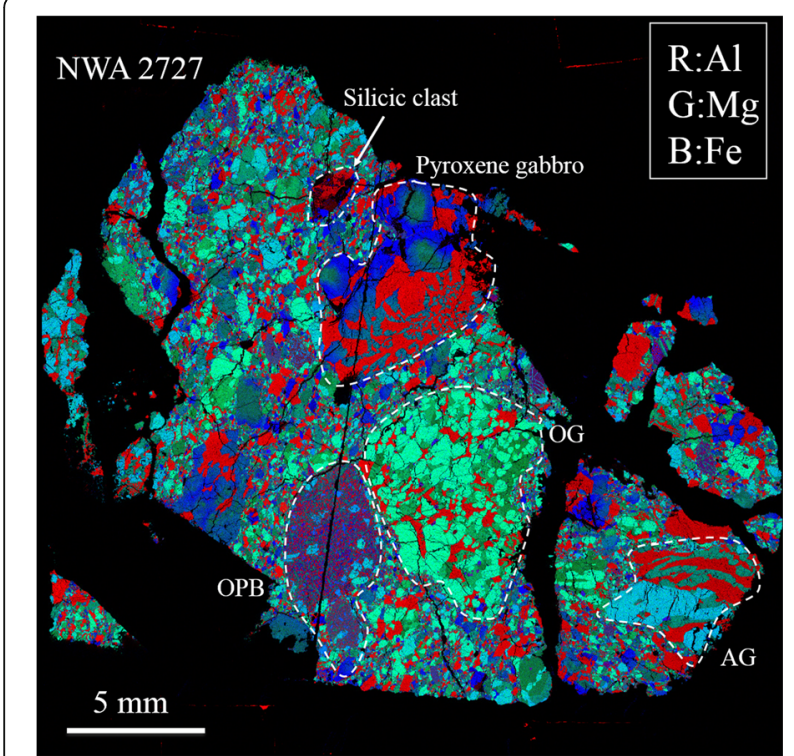

Fig. 1 False-color X-ray elemental image of NWA 2727 breccia modified after Kayama et al. (2018). Red, green, and blue (RGB) represent $\mathrm{Al}, \mathrm{Mg}$, and Fe, respectively. Ka X-rays were used for all elements. Clast name abbreviations: $O G$ olivine gabbro, $A G$ anorthositic gabbro, OPB olivine-phyric basalt
Plagioclase is present in the center of the clast and tends to be in contact with silica (Fig. 3c, d). Silica occurs as (1) massive to elongate grains up to $550 \mu \mathrm{m}$ in long diameter (labeled $\mathrm{Si}^{(1)}$ in Fig. 3d); (2) narrow domains enveloping thin plagioclase feldspar laths $\left(\sim 50 \mu \mathrm{m}\right.$ across) (labeled $\mathrm{Si}^{(2)}$ in Fig. $3 \mathrm{~d}$ ); and (3) elongate crystals intergrown with K-Ba-feldspar (labeled $\mathrm{Si}^{(3)}$ in Fig. 3d). K-Ba-feldspar is not as abundant as plagioclase or silica, but comprises approximately $15 \mathrm{vol} \%$ of the mode in the clast and appears to have co-crystallized with silica. Most of the mafic minerals occur in a cluster of olivine $(310 \mu \mathrm{m} \times 260 \mu \mathrm{m})$, pyroxene, and apatite near the left margin of the clast as shown in Fig. 3c, d. In this part of the clast, fine pyroxene crystals $(<100 \mu \mathrm{m}$; Px fine1 in Fig. 3c) occur adjacent to apatite. Pyroxene also occurs as fine clusters of crystals disseminated among silica and feldspar near the right margin of the clast $(<100 \mu \mathrm{m}$; Px fine2 in Fig. 3c), and one coarser crystal $(210 \mu \mathrm{m} \times 140 \mu \mathrm{m})$ occurs near the bottom of the clast (Px crs in Fig. 3c).

Silica is abundant in the clast, constituting nearly $40 \%$ of the mode (Table 1). Silica polymorphs were determined using micro-Raman spectroscopy in digital maps of three localities within the clast (Fig. 3e-h). Most spectra showed weak bands indicative of poor crystallinity, a

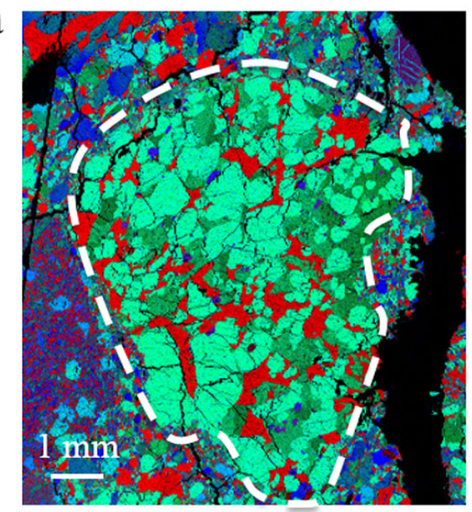

$\mathrm{C}$

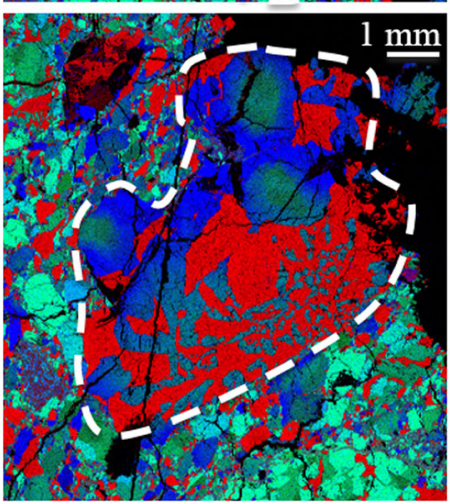

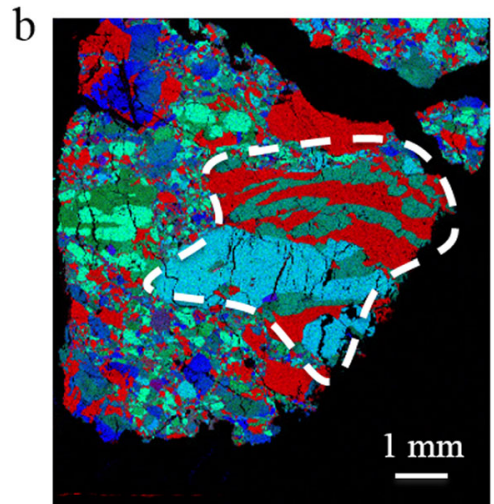

d

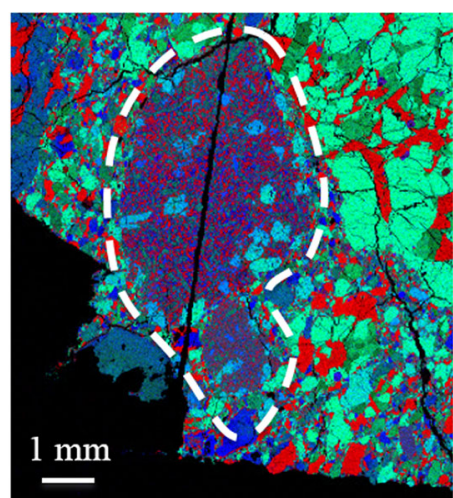

Fig. 2 False-color $X$-ray elemental images of mafic lithologies of NWA 2727. Detailed explanations of each figure are as follows: a olivine gabbro $(\mathrm{OG})$; b anorthositic gabbro (AG); c pyroxene gabbro; $\mathbf{d}$ olivine-phyric basalt (OPB). $\mathrm{RGB}$ elemental map with $\mathrm{R}=\mathrm{Al}, \mathrm{G}=\mathrm{Mg}, \mathrm{B}=\mathrm{Fe}$ 
but some points yielded spectral patterns characteristic of tridymite, cristobalite, and quartz, all present within the clast (Fig. 4). Quartz was identified only where silica is intergrown with $\mathrm{K}$-Ba-feldspar, whereas cristobalite and tridymite were found where the silica has a more massive texture (Fig. 3e-h).

Mafic mineral crystals in the silicic clast are much finer-grained ( $0.3 \mathrm{~mm}$ in maximum dimension) than those of three gabbros (OG, AG, FG), and similar in size to olivine phenocrysts in the OPB. The finer-grained texture of the silicic clast indicates more rapid cooling history than those of the three gabbros. Silica minerals with abundant plagioclase feldspar were not identified in OG, AG, and FG lithologies in this PTS. The silicic clast occurs isolated in breccia, and has no spatial or zoning relationships with those gabbros. Some of FG clasts (symplectite and ARFe) in other portions of NWA 773 clan include silica minerals (Fagan et al. 2014; Valencia et al. 2019), but the modal abundances of silica are less and grain sizes are smaller than silica of the silicic clast.

\section{Mineral compositions in the silicic clast}

Olivine and ilmenite in the silicic clast have Fe\# (molar Fe/ $[\mathrm{Fe}+\mathrm{Mg}] \times 100)$ of $99-100$ (Table 2) corresponding to late-stage magmatic crystallization. All of the pyroxene analyses indicate hedenbergitic compositions with Fe\# and Ti\# both $\geq 99(\mathrm{Ti} \#=$ molar $\mathrm{Ti} /[\mathrm{Ti}+\mathrm{Cr}] \times 100)($ Table 2; Figs. 5 and 6). Fine pyroxene crystals that are interwoven with apatite in the mafic cluster and the coarse pyroxene have essentially identical Wo-En-Fs compositions; the fine pyroxene near the upper right margin (Px fine2 in Fig. 3) has slightly lower Wo-content $\left(\mathrm{Wo}_{36-38}\right.$ in Fig. 5). All pyroxenes in the silicic clast are more ferroan than those in the ARFe clasts analyzed by Fagan et al. (2014) (Figs. 5 and 6). All analyzed pyroxenes from the silicic clast have a Ti/ $\mathrm{Al}$ ratio ranging from 0.4 to 0.6 with an average value of 0.5 as shown in Fig. 6a. In lunar basaltic rocks, low $\mathrm{Ti} / \mathrm{Al}(\sim 0.25)$ is associated with pyroxene that crystallized prior to feldspar, whereas higher Ti/Al $(\sim 0.5)$ indicates pyroxene that crystallized after feldspar crystallization had started (Bence et al. 1970; Fagan et al. 2014). Thus, it is likely that all of the pyroxene from the clast crystallized after the onset of feldspar crystallization. The high $\mathrm{Fe} \#$ and $\mathrm{Ti} \#$ are consistent with late-stage crystallization in an igneous system (Fig. 6b).

Plagioclase has chemical compositions near $\mathrm{An}_{87}$ with limited $\mathrm{Ab}$-An zoning $\left(\mathrm{An}_{82-91}\right.$; Table 3$)$. The An value is higher than those of plagioclase in the Apollo granitic samples $\left(\mathrm{An}_{80-50}\right.$; Wieczorek et al. 2006). The FeO content in plagioclase $(1.15 \mathrm{wt} \%)$ is higher than those in the Apollo granite/felsite (0.06-0.79 wt\%: Warren et al. 1983; Jolliff 1991; Seddio et al. 2013, 2015) and KREEP basalt (0.16-0.71 wt\%: Simon et al. 1988; Papike et al.
1991), and the FeO content in plagioclase of the silicic clast is as high as those of the Apollo very-low-Ti mare basalt (0.90-1.34 wt\% in Papike et al. 1991). Minor $\mathrm{K}_{2} \mathrm{O}$ $\left(\mathrm{Or}_{\sim 2}\right)$ was detected in all analyses of plagioclase and $\mathrm{BaO}$ was detected in some analyses, though only in minor concentrations $(<0.2 \mathrm{wt} \% \mathrm{BaO})$. Alkali feldspar is enriched in $\mathrm{K}$, with minor $\mathrm{Na}$, detectable $\mathrm{Ca}$, and variable $\mathrm{Ba}\left(\mathrm{Ab}_{3} \mathrm{~A}\right.$ $\left.\mathrm{n}_{2} \mathrm{Or}_{95} \mathrm{Cn}_{0}-\mathrm{Ab}_{4} \mathrm{An}_{2} \mathrm{Or}_{81} \mathrm{Cn}_{13}\right)$. The $\mathrm{BaO}$ concentration in the $\mathrm{K}-\mathrm{Ba}$-feldspar is zoned (0.1-6.7 wt\%). Analyses of silica are mostly $\mathrm{SiO}_{2}$, with minor $\mathrm{TiO}_{2}$ (mostly 0.1 to $0.2 \mathrm{wt} \%$ ); $\mathrm{K}_{2} \mathrm{O}$ and $\mathrm{Al}_{2} \mathrm{O}_{3}$ were detected during analyses, possibly due to beam overlap with adjacent feldspar. However, as noted by Seddio et al. (2015), the hightemperature polymorphs of silica have more open structures than quartz and thus, may accommodate elevated concentrations of minor elements. The silicic clast formed at or near the lunar surface at a cooling rate fast enough to preserve cristobalite and tridymite. Zoning of $\mathrm{BaO}$ concentration in K-Ba-feldspar is consistent with a fast cooling rate, as are the fine grain sizes of mafic minerals in the silicic clast. These features indicate that this clast is not plutonic rock, but rather derived from volcanic or near-surface origin. On the IUGS classification of volcanic rocks based on modal abundances of silica, alkali feldspar, and plagioclase, this clast falls on the boundary between rhyolite and dacite (Fig. 7).

\section{Comparison of major element composition of the silicic clast with other lithologies in NWA 773 clan}

The whole rock composition of the silicic clast was determined by modal recombination (Table 4) using modal abundances, densities of minerals, and their elemental concentrations. All $\mathrm{Fe}$ is calculated as $\mathrm{Fe}^{2+}$. And the density of all $\mathrm{SiO}_{2}$ is used as $2.2 \mathrm{~g} \mathrm{~cm}^{-3}$, which is comparable to the density of cristobalite (Holland and Powell 2011). Based on bulk $\mathrm{SiO}_{2}$ and $\mathrm{Na}_{2} \mathrm{O}+\mathrm{K}_{2} \mathrm{O}$ contents, the silicic clast falls along andesite-dacite boundary on the total alkali-silica (TAS) diagram of Le Bas et al. (1992); Fig. 8). This clast is characterized as a dacite on the basis of the low-pressure origin indicated by cristobalite and tridymite combined with the bulk composition.

The bulk composition of the dacite clast is compared with those of other clast lithologies (OG, AG, FG, OPB) in NWA 773 clan and the Apollo quartz monzodiorite (QMD), granite, and felsite in Table 4. The dacite clast is more enriched in $\mathrm{SiO}_{2}$ and alkali elements $(\mathrm{Na}, \mathrm{K}, \mathrm{Ba})$ than other lithologies of NWA 773 clan. Furthermore, the bulk composition of the dacite $(\mathrm{Mg \#}<1)$ is much more ferroan than other NWA 773 clan lithologies that were analyzed by Valencia et al. (Mg\# ${ }_{51-70}$, see Table 4$)$. From the above results, the dacite clast appears to be a distinct lithology from the existing lithologies in the NWA 773 clan. On the other hand, the concentrations of $\mathrm{SiO}_{2}$ and 

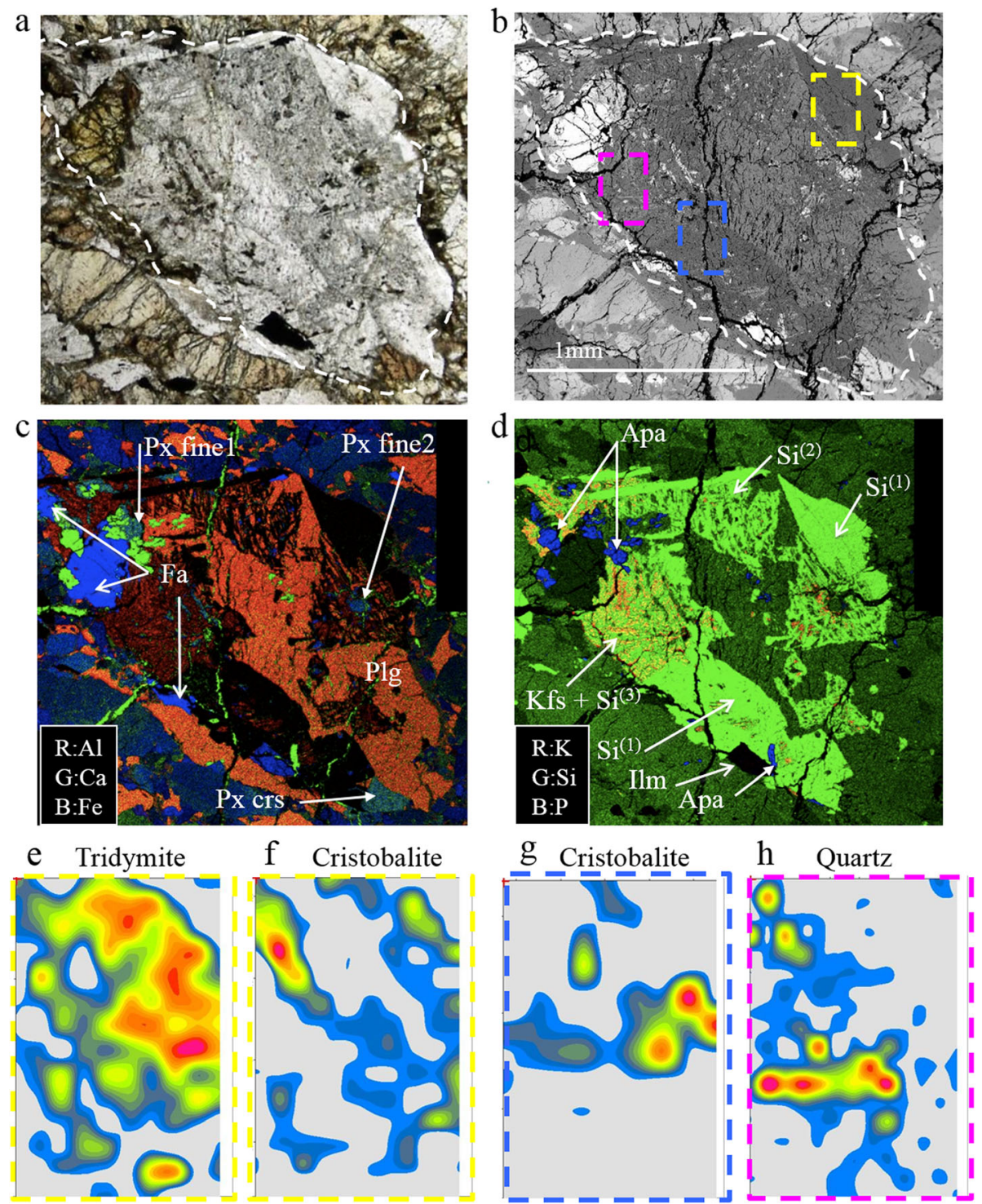

Fig. 3 Images of silicic clast and Raman maps showing silica polymorphs. Detailed explanations of each figure are as follows: a photomicrograph in plane polarized light; $\mathbf{b}$ back-scattered electrons (BSE); $\mathbf{c} R G B$ elemental map with $R=A l, G=C a, B=F e$, d RGB image with $R=K, G=S i, B=P$. Silica occurs as: (1) massive to elongate grains; (2) narrow domains enveloping thin plagioclase feldspar laths; and (3) elongate crystals intercalated with K-Ba-feldspar. Areas where Raman peaks were mapped are color-coded in panel $\mathbf{b}$, with maps $\mathbf{e}$, $\mathbf{f}$ enclosed in the yellow box, map $\mathbf{g}$ in the blue box, and map $\mathbf{h}$ in the purple box. The Raman peak intensity maps show the following peaks: e peak intensity at $351 \mathrm{~cm}^{-1}$ (tridymite); $\mathbf{f}$ peak intensity at $411 \mathrm{~cm}^{-1}$ (cristobalite); $\mathbf{g}$ peak intensity at $411 \mathrm{~cm}^{-1}$ (cristobalite); h peak intensity at $464 \mathrm{~cm}^{-1}$ (quartz). Warm colors (red) indicate high peak intensities and dark (blue) colors denote low intensities. Mineral abbreviations: Apa apatite, Fa fayalite, Ilm ilmenite, Kfs K-feldspar, Plg plagioclase, Px pyroxene, Si silica

alkali elements in the dacite are not as high as those in the Apollo granite and felsite. The bulk $\mathrm{P}_{2} \mathrm{O}_{5}$ content $(1.3 \mathrm{wt} \%)$ in the dacite clast is higher than those (0.0860.34 wt\%) of other lithologies in NWA 773 clan and Apollo granite/felsite (0.05-0.20 wt\%: Quick et al. 1977; Seddio et al. 2013), but falls in the range of $\mathrm{P}_{2} \mathrm{O}_{5}$ concentrations of QMD (0.25-1.72 wt\%: Taylor et al. 1980; Ryder and Martinez 1991; Jolliff et al. 1993; Fagan et al. 2014).

\section{Discussion}

Comparisons of the dacite clast with other lunar silicic rocks The high Fe\# of mafic silicates combined with the abundance of silica in the dacite clast can be explained by crystallization from a residual liquid after fractional crystallization. Some of the silica in the clast is intergrown with feldspars, suggesting co-crystallization of silica with plagioclase and alkali feldspars during stages of crystallization from liquid. The interlocking textures of 
Table 1 Modal abundances (vol\%) of minerals in the NWA 2727 silicic clast, Apollo granite, QMD

\begin{tabular}{|c|c|c|c|c|c|}
\hline Sample name & NWA 2727 & $12033,634-34$ & $12023,14-10$ & $12032,366-19$ & 15405,145 \\
\hline Clast & Silicic clast & Granite & Granite & Granite & QMD \\
\hline Refer. & this work & Seddio et al. (2015) & Seddio et al. (2014) & Seddio et al. (2013) & Fagan et al. (2014 \\
\hline $\mathrm{Ol}$ & 4.9 & 7.1 & 0.8 & 2.8 & - \\
\hline LCP & - & 8.7 & 2.2 & 5.5 & 12.1 \\
\hline $\mathrm{HCP}$ & 5.9 & & & & 13.7 \\
\hline Plg & 31.4 & 30.3 & 14.2 & 6.3 & 20.2 \\
\hline Kfs & 14.9 & 21.1 & 45.7 & 52.3 & 24.5 \\
\hline $\mathrm{Si}$ & 39.4 & 24.0 & 36.7 & 32.0 & 23.8 \\
\hline Ox & $<1$ & 1.0 & $<1$ & $<2$ & 2.3 \\
\hline Ap & 2.6 & 4.0 & $\operatorname{Tr}$ & $\operatorname{Tr}$ & 0.3 \\
\hline Mer & - & 3.9 & - & $\operatorname{Tr}$ & 2.8 \\
\hline
\end{tabular}

Ol olivine, LCP low-Ca pyroxene (pigeonite + orthopyroxene), HCP high-Ca pyroxene (augite), Plg plagioclase, Kfs K-feldspar, Si silica, Ox oxide phases, Ap apatite, Mer merrillite, $\operatorname{Tr}$ trace amount. The unit of modal abundances in Seddio et al. $(2013,2014)$ are converted into "vol\%" from "wt\%"

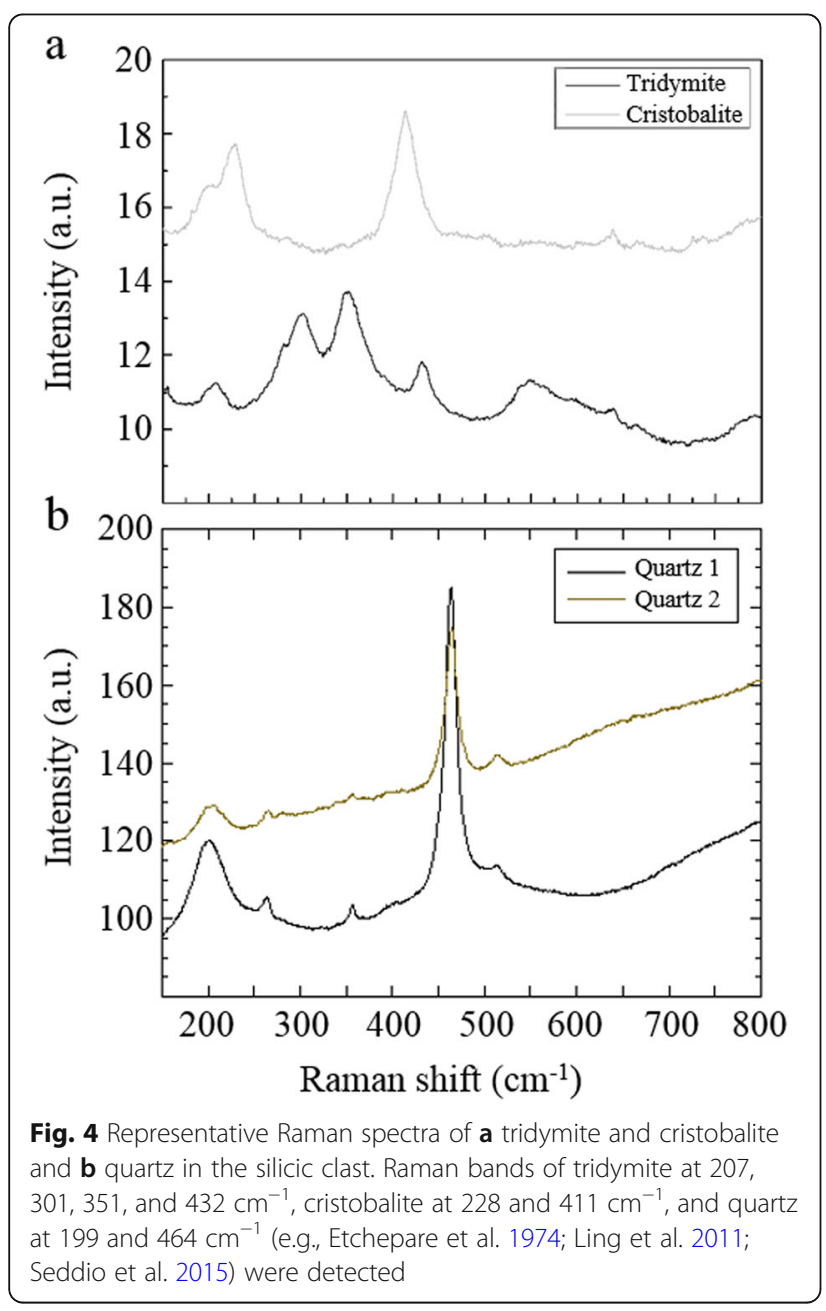

the dacite clast are distinct from granulitic textures (mainly minerals having rounded shapes) associated with silicic rocks formed by impact, and no shock melt pockets were observed (Takeda 1986; Barrat et al. 2009; Takeda et al. 2015). Moganite, a monoclinic $\mathrm{SiO}_{2}$ polymorph associated with carbonaceous chondrite-derived lunar alkaline fluid that becomes a source of subsurface ice deposits, has been identified along with the highpressure polymorphs coesite in matrix grains and stishovite in some shock veins elsewhere in NWA 2727 (Kayama et al. 2018). Some portions of cristobalite and tridymite also occur in silica micrograins in the shock veins, which apparently transformed from moganite during post-shock decompression. However, the coarse grain sizes and intergrown feldspar texture of the dacite clast are distinct from the shock-related occurrences of silica identified by Kayama et al. (2018). Therefore, the formation of tridymite and cristobalite in the dacite clast by unloading after shock impact can be excluded; a shock melt origin of the dacite clast is unlikely. We infer that this clast crystallized from silicic melt that formed by endogenic igneous processes on the Moon.

The occurrence of three low-pressure silica polymorphs indicates rapid, near-surface cooling, and disequilibrium. Cristobalite and tridymite observed in the clast are thought to have been quenched from conditions of low pressures $(<1 \mathrm{GPa})$ and high temperatures $\left(\sim 870\right.$ to $\sim 1500{ }^{\circ} \mathrm{C}$ ) (e.g., Presnall 1995; Koike et al. 2013). These silica polymorphs are also found in silicic volcanic settings in terrestrial settings (e.g., Baxter et al. 1999; Hamasaki 2002; Horwell et al. 2010), and the presence of tridymite on the surface of Mars has been interpreted as an indicator of silicic volcanism (Morris et al. 2016). The presence of cristobalite provides evidence of higher crystallization temperature (Koike et al. 2013) 
Table 2 Average compositions of olivine, pyroxene and ilmenite in the silicic clast

\begin{tabular}{|c|c|c|c|c|c|c|}
\hline \multirow{3}{*}{$\begin{array}{l}\mathrm{n} \\
\mathrm{wt} \% \\
\end{array}$} & \multicolumn{2}{|c|}{ Olivine } & \multicolumn{2}{|c|}{ Pyroxene } & \multicolumn{2}{|c|}{ Ilmenite } \\
\hline & \multicolumn{2}{|l|}{4} & \multicolumn{2}{|l|}{10} & \multicolumn{2}{|l|}{2} \\
\hline & mean & s.d. & mean & s.d. & mean & s.d. \\
\hline $\mathrm{SiO}_{2}$ & 30.53 & 0.27 & 46.48 & 0.71 & 0.06 & 0.04 \\
\hline $\mathrm{TiO}_{2}$ & 0.06 & 0.02 & 0.99 & 0.28 & 51.29 & 0.23 \\
\hline $\mathrm{Al}_{2} \mathrm{O}_{3}$ & $<0.03$ & & 1.32 & 0.37 & 0.06 & 0.02 \\
\hline $\mathrm{Cr}_{2} \mathrm{O}_{3}$ & $<0.04$ & & $<0.04$ & & $<0.04$ & \\
\hline $\mathrm{FeO}$ & 68.91 & 0.58 & 32.87 & 2.16 & 47.32 & 0.70 \\
\hline $\mathrm{MnO}$ & 0.81 & 0.11 & 0.34 & 0.04 & 0.43 & 0.15 \\
\hline $\mathrm{MgO}$ & 0.15 & 0.03 & 0.12 & 0.06 & 0.04 & 0.04 \\
\hline $\mathrm{CaO}$ & 0.63 & 0.11 & 18.54 & 1.75 & 0.07 & 0.02 \\
\hline $\mathrm{Na}_{2} \mathrm{O}$ & 0.05 & 0.02 & 0.04 & 0.02 & $<0.02$ & \\
\hline $\mathrm{K}_{2} \mathrm{O}$ & $<0.01$ & & $<0.01$ & & 0.01 & 0.00 \\
\hline $\mathrm{P}_{2} \mathrm{O}_{5}$ & 0.06 & 0.03 & $<0.03$ & & $<0.03$ & \\
\hline $\mathrm{BaO}$ & na & & 0.07 & 0.04 & na & \\
\hline Total & 101.2 & & 100.8 & & 99.3 & \\
\hline at. per oxy at. & 4 & & 6 & & 3 & \\
\hline Si & 1.013 & 0.006 & 1.927 & 0.025 & 0.002 & 0.001 \\
\hline $\mathrm{Ti}$ & 0.001 & 0.001 & 0.031 & 0.009 & 0.985 & 0.001 \\
\hline $\mathrm{Al}$ & b.d. & & 0.065 & 0.018 & 0.002 & 0.001 \\
\hline $\mathrm{Cr}$ & b.d. & & b.d. & & b.d. & \\
\hline $\mathrm{Fe}$ & 1.912 & 0.015 & 1.140 & 0.077 & 1.011 & 0.010 \\
\hline $\mathrm{Mn}$ & 0.023 & 0.003 & 0.012 & 0.001 & 0.009 & 0.003 \\
\hline Mg & 0.007 & 0.001 & 0.008 & 0.003 & 0.002 & 0.002 \\
\hline $\mathrm{Ca}$ & 0.022 & 0.004 & 0.823 & 0.076 & 0.002 & 0.000 \\
\hline $\mathrm{Na}$ & 0.004 & 0.001 & 0.003 & 0.002 & b.d. & \\
\hline K & b.d. & & b.d. & & 0.000 & 0.000 \\
\hline P & 0.002 & 0.001 & b.d. & & b.d. & \\
\hline $\mathrm{Ba}$ & na & & 0.001 & 0.001 & na & na \\
\hline total & 2.984 & & 4.010 & & 2.013 & \\
\hline Fe\# & 99.8 & & 99.3 & & 99.8 & \\
\hline Wo & & & 41.8 & & & \\
\hline En & & & 0.4 & & & \\
\hline Fs & & & 57.8 & & & \\
\hline Ti\# & & & 99.9 & & & \\
\hline Ti/Al & & & 0.48 & & & \\
\hline
\end{tabular}

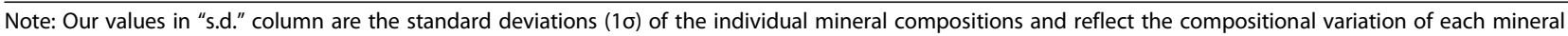
in the silicic clast. The word of " $n$ " means number of analyses, "b.d." means below the detection limit, "n.a." means no analysis

than typical lunar granitic samples $\left(\mathrm{T}<1000{ }^{\circ} \mathrm{C}\right.$ ) (Jolliff et al. 1999; Gullikson et al. 2016). The occurrence of three low-pressure silica polymorphs in the same rock is unusual; however, Seddio et al. (2015) observed hackle fracture patterns in quartz in Apollo samples of lunar granites, and inferred that the fractures formed by a volume reduction during recrystallization from cristobalite or tridymite to quartz. The phase transition to quartz would depend on cooling rate. The dacite clast probably crystallized at a relatively fast cooling rate that resulted in incomplete transformation of the high-T polymorphs to quartz. The poor crystallinity of much of the silica in the clast is likely due to rapid cooling during crystallization. 


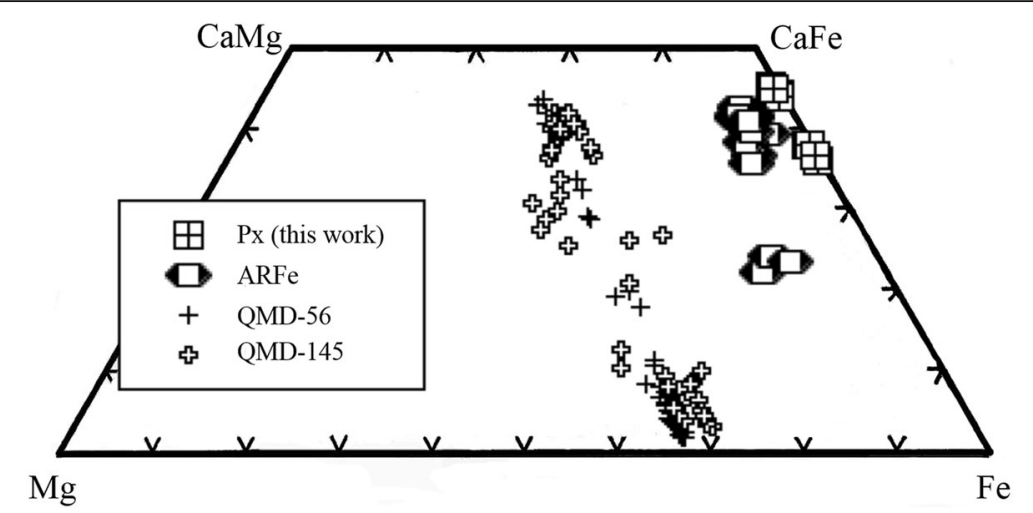

Fig. 5 Pyroxene quadrilateral compositions from the silicic clast (this work). Compositions reported by Fagan et al. (2014) for pyroxenes from NWA 773 ARFe clasts and 15405 QMD $(56,145)$, are also shown

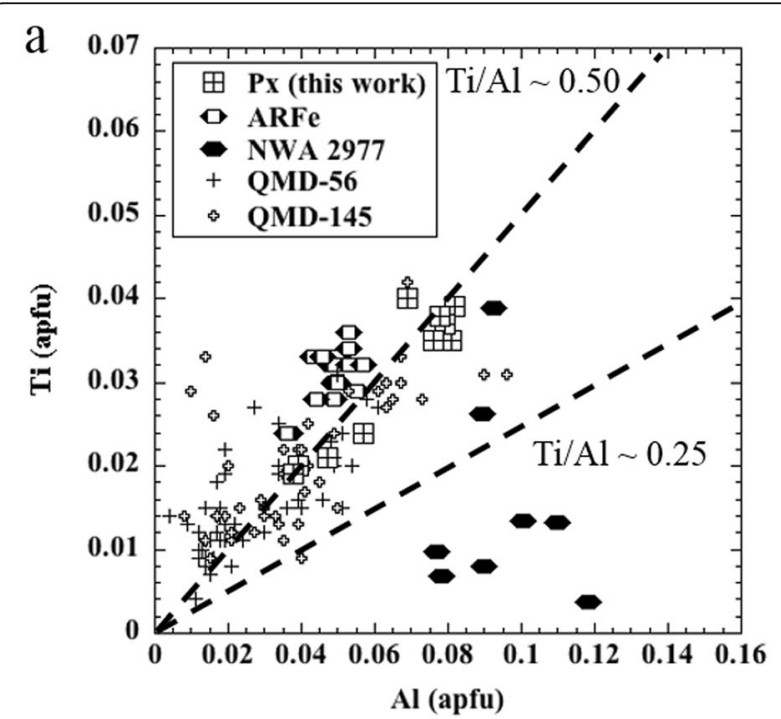

$\mathrm{b}$

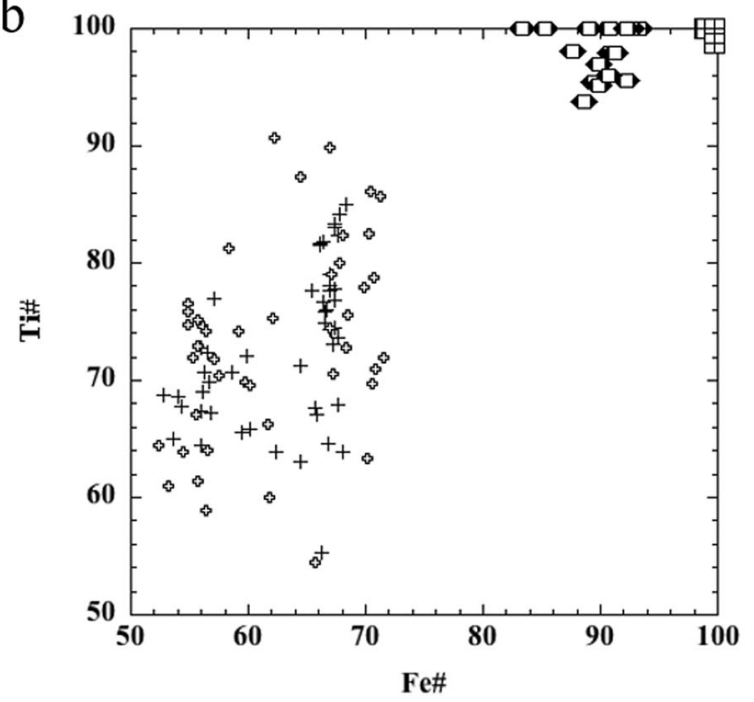

Fig. 6 a Al versus Ti and $\mathbf{b}$ Fe\# versus Ti\# in pyroxenes from the silicic clast (this work). Compositions of ARFe clasts in NWA 773 (Fagan et al. 2014), NWA 2977 OG (Nagaoka et al. 2015), and 15405 QMD $(56,145)$ (Fagan et al. 2014) are also shown
Other silica-bearing igneous clasts in NWA 773 clan include clinopyroxene-phyric basalt (CPB) clasts, symplectite, and alkaline-phase-ferroan (ARFe) clasts (Fagan et al. 2014; Kayama et al. 2018). The symplectite and ARFe classifications of Fagan et al. (2014) are grouped together as variations within ferroan gabbro (FG) by Valencia et al. (2019), but both groups of workers (Fagan et al. 2014; Valencia et al. 2019) report similar textures and mineral compositions. The CPB clasts have anhedral quartz single crystals on the order of $\leq 40 \mu \mathrm{m}$ across and have abundant pyroxene + feldspar-rich groundmass, distinct from the dacite clast (Kayama et al. 2018). The symplectite (one variety of FG of Valencia et al. 2019) is composed of fayalite, silica, and hedenbergitic pyroxene with curved, fine intermingled textures (Fagan et al. 2003, 2014; Jolliff et al. 2003). Fayalite, silica, and hedenbergitic pyroxene also occur in the dacite clast, but feldspars also are abundant in the clast, and the textures and formation processes are distinct. Whereas the symplectites formed dominantly by pyroxferroite breakdown (Fagan et al. 2003, 2014; Jolliff et al. 2003; Valencia et al. 2019), textures in the dacite clast are consistent with formation by igneous crystallization from melt.

Igneous textures, such as elongate K-feldspar intergrown with silica, also occur in some ARFe clasts of NWA 773 (Fagan et al. 2014; approximately equivalent to silica-K-feldspar granophyre-bearing clasts of Jolliff et al. 2003, and grouped within the FG lithology of Valencia et al. 2019, see their Figs. 9-11 of FG-A, FG-B, FG-C, FG-D, FG-F, FG-I). The presence of ferroan mafic silicates, silica, feldspar, and Ca-phosphates are common to the FG/ARFe lithology (combining the classification schemes of Fagan et al. 2014 and Valencia et al. 2019) and the dacite clast, and textures in FG/ARFe rocks and dacite clast indicate igneous origin. In detail, however, the two lithologies are distinct. In the FG/ARFe clasts, 
Table 3 Average compositions of plagioclase, K,Ba-feldspar and silica in the silicic clast

\begin{tabular}{|c|c|c|c|c|c|c|}
\hline \multirow{3}{*}{$\begin{array}{l}\mathrm{n} \\
\mathrm{wt} \%\end{array}$} & \multicolumn{2}{|c|}{ Plagioclase } & \multicolumn{2}{|c|}{ K,Ba-feldspar } & \multicolumn{2}{|l|}{ Silica } \\
\hline & \multicolumn{2}{|l|}{13} & \multicolumn{2}{|l|}{6} & \multicolumn{2}{|l|}{11} \\
\hline & mean & s.d. & mean & s.d. & mean & s.d. \\
\hline $\mathrm{SiO}_{2}$ & 47.29 & 1.13 & 62.81 & 1.86 & 99.61 & 0.78 \\
\hline $\mathrm{TiO}_{2}$ & $<0.05$ & & 0.18 & 0.12 & 0.16 & 0.03 \\
\hline $\mathrm{Al}_{2} \mathrm{O}_{3}$ & 31.91 & 1.14 & 19.57 & 0.60 & 0.55 & 0.18 \\
\hline $\mathrm{Cr}_{2} \mathrm{O}_{3}$ & $<0.04$ & & $<0.04$ & & $<0.04$ & \\
\hline $\mathrm{FeO}$ & 1.15 & 0.29 & 0.14 & 0.05 & 0.11 & 0.08 \\
\hline $\mathrm{MnO}$ & $<0.04$ & & $<0.04$ & & $<0.04$ & \\
\hline $\mathrm{MgO}$ & $<0.02$ & & $<0.02$ & & $<0.02$ & \\
\hline $\mathrm{CaO}$ & 18.14 & 0.79 & 0.31 & 0.12 & 0.05 & 0.03 \\
\hline $\mathrm{Na}_{2} \mathrm{O}$ & 1.26 & 0.25 & 0.42 & 0.04 & 0.09 & 0.04 \\
\hline $\mathrm{K}_{2} \mathrm{O}$ & 0.33 & 0.14 & 14.61 & 1.00 & 0.28 & 0.14 \\
\hline $\mathrm{P}_{2} \mathrm{O}_{5}$ & $<0.03$ & & $<0.03$ & & $<0.03$ & \\
\hline $\mathrm{BaO}$ & 0.09 & 0.05 & 3.45 & 2.30 & 0.03 & 0.02 \\
\hline Total & 100.17 & & 101.49 & & 100.88 & \\
\hline atoms per oxy at. & 8 & & 8 & & 2 & \\
\hline $\mathrm{Si}$ & 2.187 & 0.051 & 2.919 & 0.050 & 0.992 & 0.002 \\
\hline $\mathrm{Ti}$ & b.d. & & 0.007 & 0.004 & 0.001 & 0.000 \\
\hline $\mathrm{Al}$ & 1.740 & 0.058 & 1.073 & 0.046 & 0.006 & 0.002 \\
\hline $\mathrm{Cr}$ & b.d. & & b.d. & & b.d. & \\
\hline $\mathrm{Fe}$ & 0.045 & 0.011 & 0.005 & 0.002 & 0.001 & 0.001 \\
\hline $\mathrm{Mn}$ & b.d. & & b.d. & & b.d. & \\
\hline $\mathrm{Mg}$ & b.d & & b.d. & & b.d. & \\
\hline $\mathrm{Ca}$ & 0.899 & 0.038 & 0.016 & 0.006 & 0.001 & 0.000 \\
\hline $\mathrm{Na}$ & 0.113 & 0.023 & 0.038 & 0.004 & 0.002 & 0.001 \\
\hline K & 0.020 & 0.008 & 0.866 & 0.049 & 0.003 & 0.002 \\
\hline P & b.d & & b.d. & & b.d. & \\
\hline $\mathrm{Ba}$ & 0.002 & 0.001 & 0.063 & 0.043 & 0.000 & 0.000 \\
\hline total & 5.006 & & 4.987 & & 1.006 & \\
\hline$A b$ & 10.9 & & 3.9 & & & \\
\hline An & 87.0 & & 1.6 & & & \\
\hline Or & 1.9 & & 88.1 & & & \\
\hline $\mathrm{Cn}$ & 0.2 & & 6.4 & & & \\
\hline
\end{tabular}

Note: Our values in "s.d." column are the standard deviations $(1 \sigma)$ of the individual mineral compositions and reflect the compositional variation of each mineral in the silicic clast. The number of analyses is indicated by " $n$ ", "b.d." means below the detection limit. The BaO content was determined in 11 of the 13 analyses of plagioclase feldspar

K-feldspar is more abundant than plagioclase, but the reverse is true for the dacite clast. The main Ca-phosphate in the FG/ARFe lithology is merrillite, whereas only apatite has been identified in the dacite clast. Finally, although K-feldspar and silica are characteristic of the FG/ ARFe clasts, they typically occur in minor modal abundances compared to mafic silicates. In contrast, feldspars and silica are much more abundant than mafic phases in the dacite clast. The differences in mineral modes reflect the high bulk $\mathrm{SiO}_{2}$ content of the dacite compared to the FG/ARFe clasts (Fagan et al. 2014; Valencia et al. 2019), suggesting differences in origin.

Therefore, although the dacite clast shares several features of the FG/ARFe lithology described by Fagan et al. (2014) and Valencia et al. (2019), the dacite clast appears to be a new lithology in the NWA 773 clan, which has not been described previously. While we cannot rule out the possibility that the dacite clast is an unusual variety 


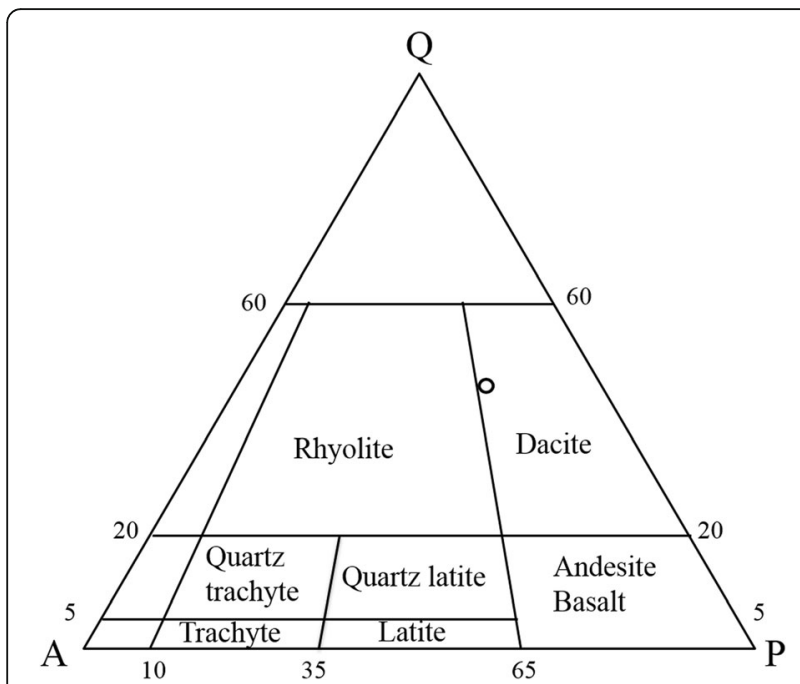

Fig. 7 IUGS Classification of volcanic rocks (Streckeisen 1979). White circle plot represents the silicic clast (this work)

of the FG/ARFe lithology, the high $\mathrm{SiO}_{2}$-content, high ratio of plagioclase/K-feldspar and occurrence of apatite without merrillite all point toward a distinct origin for the dacite clast (see "Petrogenesis of the dacite clast" section for further discussion).

The whole-rock composition distinguishes the dacite clast from other lunar silicic rocks such as QMD and granite. In Fig. 9, the bulk composition of the dacite clast is compared with lunar evolved rocks returned by Apollo missions (KREEP basalt, QMD, granite/felsite, granitic breccia) (Hubbard et al. 1973; Rhodes and Hubbard 1973; Murali et al. 1977; Quick et al. 1977; Warren and Wasson 1978; Warren et al. 1978; Taylor et al. 1980; Warren et al. 1983; Salpas et al. 1987; Lindstrom et al. 1988; Simon et al. 1988; Morris et al. 1990; Jolliff et al. 1991; Marvin et al. 1991; Ryder and Martinez 1991; Snyder et al. 1992; Jolliff et al. 1993; Seddio et al. 2013; Fagan et al. 2014). Lunar sample return missions collected no dacite or andesite samples (that have yet been identified), so several analyses of terrestrial ferroan $(\mathrm{Mg \#}<50)$ andesite and dacite (Shimazu et al. 1985; Gust and Arculus 1986; Imai et al. 1995; Togashi et al. 2000; Sensarma and Palme 2013) are plotted in Fig. 9 for the comparison.

The dacite clast plots between QMD and lunar granitic rocks in terms of $\mathrm{SiO}_{2}$ versus $\mathrm{MgO}+\mathrm{FeO}$ contents (Fig. 9a), and is distinct from the clusters of lunar KREEP basalts, QMD, and granitic rocks in terms of $\mathrm{SiO}_{2}$ versus $\mathrm{Al}_{2} \mathrm{O}_{3}$ (Fig. 9b). In both cases, the clast is similar to some of the terrestrial ferroan andesite/dacite samples. However, the dacite clast has lower $\mathrm{Na}_{2} \mathrm{O}+$ $\mathrm{K}_{2} \mathrm{O}$ contents at comparable $\mathrm{SiO}_{2}$ and is more ferroan than both the terrestrial andesite/dacites and lunar granitic rocks (Fig. 9c, d). The difference in alkalis reflects the lower mode of K-feldspar and the low albite content $\left(A b_{11}\right)$ of plagioclase in comparison with the Apollo granitic samples and in the terrestrial andesite/dacite. The reported whole-rock $\mathrm{Na}_{2} \mathrm{O}$ and $\mathrm{K}_{2} \mathrm{O}$ (and $\mathrm{SiO}_{2}$ ) concentrations of the dacite in NWA 773 clan depend of course on the mode of the clast, which is likely to vary

Table 4 Major element abundances of the silicic clast (this work), other lithologies (OG, AG, FG, OPB) in NWA 773 clan, and Apollo evolved samples

\begin{tabular}{|c|c|c|c|c|c|c|c|c|}
\hline \multirow[b]{3}{*}{ Oxide (wt\%) } & \multirow{3}{*}{$\begin{array}{l}\text { NWA } 2727 \\
\text { Silicic clast } \\
\text { This work }\end{array}$} & \multicolumn{4}{|c|}{ NWA 773 clan } & \multirow{3}{*}{$\begin{array}{l}\text { 15405,145 } \\
\text { QMD } \\
\text { Fagan et al. } 2014\end{array}$} & \multirow{3}{*}{$\begin{array}{l}\text { 12032, 366-19 } \\
\text { Granite } \\
\text { Seddio et al. } 2013\end{array}$} & \multirow{3}{*}{$\begin{array}{l}\text { 12013, light } \\
\text { Felsite } \\
\text { Warren et al. } 1983\end{array}$} \\
\hline & & OG & $A G$ & $F G$ & OPB & & & \\
\hline & & \multicolumn{4}{|c|}{ Valencia et al. 2019} & & & \\
\hline$\overline{\mathrm{SiO}_{2}}$ & 63.0 & 43.47 & 47.3 & 47.52 & 45.39 & 60.3 & 70.1 & 73 \\
\hline $\mathrm{TiO}_{2}$ & 0.89 & 0.36 & 0.17 & 1.07 & 0.85 & 2.15 & 1.07 & 0.6 \\
\hline $\mathrm{Al}_{2} \mathrm{O}_{3}$ & 13.5 & 5.02 & 19.5 & 6.91 & 8.01 & 10.3 & 13.5 & 11.9 \\
\hline $\mathrm{Cr}_{2} \mathrm{O}_{3}$ & $<0.1$ & 0.42 & 0.28 & 0.44 & 0.52 & 0.08 & - & - \\
\hline $\mathrm{FeO}$ & 9.3 & 19.08 & 9.58 & 19.83 & 21.72 & 11.0 & 4.98 & 0.90 \\
\hline $\mathrm{MnO}$ & $<0.1$ & 0.234 & 0.17 & 0.279 & 0.284 & 0.17 & 0.07 & - \\
\hline $\mathrm{MgO}$ & $<0.1$ & 24.65 & 7.05 & 12.92 & 12.71 & 3.18 & 0.14 & 0.7 \\
\hline $\mathrm{CaO}$ & 9.2 & 7.04 & 15.1 & 10.83 & 9.59 & 7.6 & 3.04 & 1.4 \\
\hline $\mathrm{Na}_{2} \mathrm{O}$ & 0.51 & 0.122 & 0.38 & 0.157 & 0.163 & 0.76 & 2.47 & 1.40 \\
\hline $\mathrm{K}_{2} \mathrm{O}$ & 2.3 & 0.029 & 0.04 & 0.150 & 0.018 & 3.42 & 4.58 & 6.80 \\
\hline $\mathrm{P}_{2} \mathrm{O}_{5}$ & 1.3 & 0.086 & - & 0.34 & 0.094 & 1.42 & 0.052 & - \\
\hline $\mathrm{BaO}$ & 0.54 & 0.01 & $<0.07$ & 0.03 & 0.01 & - & 0.68 & 0.65 \\
\hline Total & 100.5 & 100.5 & 99.6 & 100.5 & 99.4 & 100.4 & 100.7 & 97.4 \\
\hline Mg\# & $<1$ & 70 & 57 & 54 & 51 & 34 & 5 & 58 \\
\hline
\end{tabular}




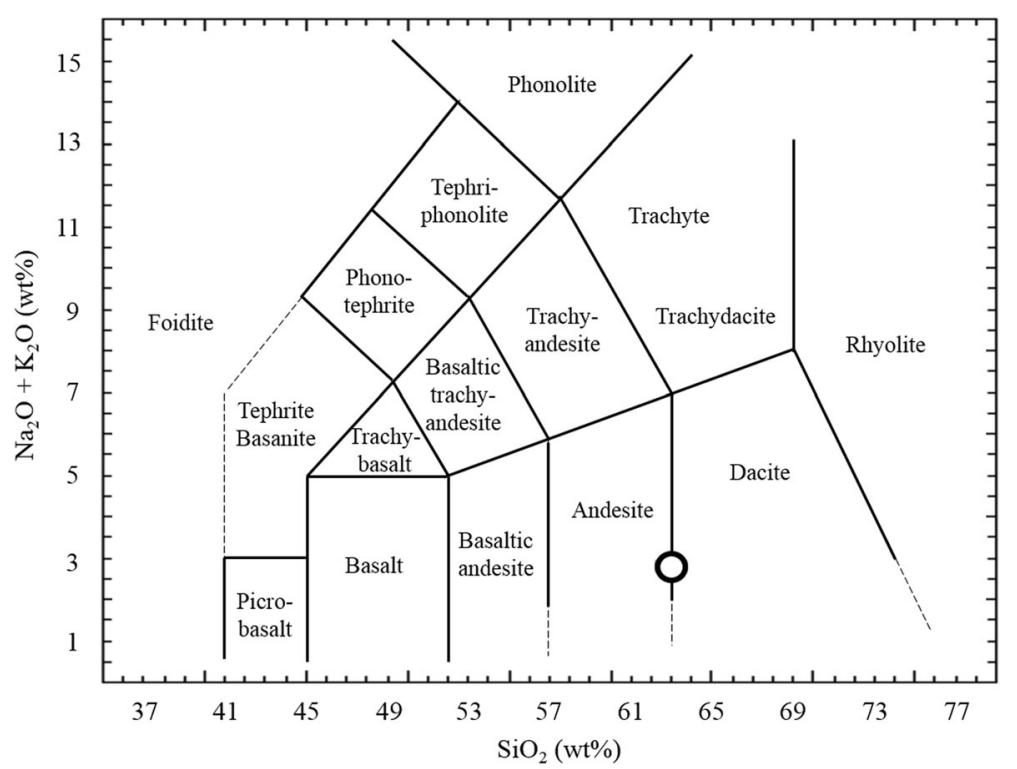

Fig. 8 Total alkali-silica (TAS) diagram (Le Bas et al. 1992). White circle represents the silicic clast (this work)

at least somewhat from the mode of the original lithology on the Moon. If the clast has disproportionately high modes of silica or low modes of feldspars, then the calculated $\mathrm{Na}_{2} \mathrm{O}+\mathrm{K}_{2} \mathrm{O}$ vs. $\mathrm{SiO}_{2}$ content could fall along the lunar variation trend shown in Fig. 9c. However, the low Ab-content of plagioclase and high Fe\# of mafic silicates of the dacite clast are distinct from the terrestrial and most of the lunar samples plotted in Fig. 9.

\section{Petrogenesis of the dacite clast}

Although there are mineralogical and compositional differences between the dacite and FG/ARFe lithology described by Fagan et al. (2014) and Valencia et al. (2019), the origin of the dacite clast is broadly similar to the origin of the FG/ ARFe lithology. Both lithologies crystallized from igneous liquids that were depleted in $\mathrm{MgO}$ and enriched in $\mathrm{SiO}_{2}$ and alkalis. Composite clasts with zoned pyroxene \pm feldspar attached to FG/ARFe domains indicate that the FG/ ARFe lithology formed after Fe-enrichment (Mg-depletion) by fractional crystallization (Fagan et al. 2014; Valencia et al. 2019). Rounded inclusions in fayalite in the FG/ARFe lithology contain igneous feldspathic glass or alkali feldspar + silica, and formed by immiscibility of alkali-silica-rich liquid from Fe-rich silicate liquid (see Rutherford et al. 1974, 1976). Spatial continuity of variations within the FG lithology (ARFe rocks, symplectites, and pyroxene gabbro), combined with mineral compositions in the OG lithology and similar $\mathrm{U}-\mathrm{Pb}$ ages of baddeleyite are strong evidence that these gabbroic rocks-OG, AG, FG lithologies- formed from a co-magmatic sequence of crystallization (Fagan et al. 2014; Shaulis et al. 2017; Valencia et al. 2019).

Whether the dacite clast also formed as part of the same NWA 773 clan co-magmatic sequence that started with OG is problematic. As described above, the high Fe\# of mafic silicates and the general mineral assemblage of the dacite are similar to the glass and feldspar + silica-bearing immiscible inclusions in FG/ARFe rocks. If the FG/ARFe immiscible inclusions coalesced, they might have formed a more coarse-grained rock similar to the dacite. However, the immiscible inclusions are dominated by alkali feldspar rather than plagioclase, and the main $\mathrm{Ca}-$ phosphate of the ARFe lithology is merrillite rather than apatite. Therefore, if the dacite formed from the alkalisilica-rich inclusions in the ARFe rocks, simple coalescence of inclusions alone is not a likely origin of the dacite. Some additional mixing with plagioclase materials or additional petrologic steps would be required to make the dacite from the ARFe inclusions. Based on the evidence currently available, we favor the interpretation that the dacite clast formed in a system independent of the olivine gabbro $\rightarrow$ anorthositic gabbro $\rightarrow$ ferroan gabbro (pyroxene gabbro + symplectite + ARFe) trend.

The presence of apatite without merrillite in the dacite clast is somewhat unusual because both Ca-phosphate minerals commonly occur together in felsic rocks from the Moon (Jolliff et al. 1993; Seddio et al. 2013, 2015; Fagan et al. 2014). However, apatite-bearing felsic rocks in which no merrillite was identified have been identified in lunar samples. Jolliff et al. (1993) reported apatite but no 

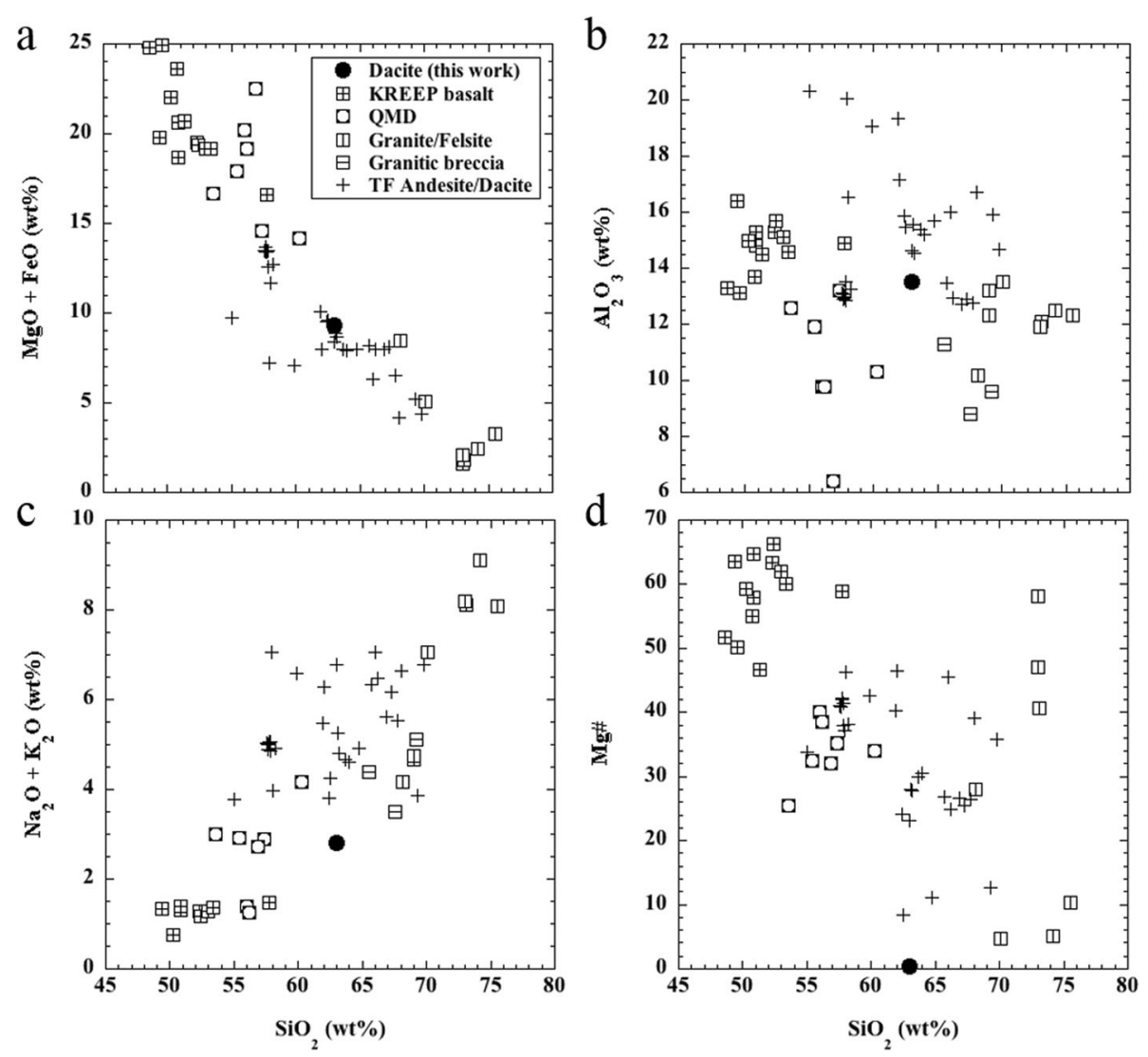

Fig. 9 Comparisons of bulk compositions between the silicic clast (Dacite; this work), Apollo evolved samples and several terrestrial andesite/ dacites (see text): $\mathbf{a} \mathrm{SiO}_{2}$ vs. $\mathrm{MgO}+\mathrm{FeO}, \mathbf{b} \mathrm{SiO}_{2}$ vs. $\mathrm{Al}_{2} \mathrm{O}_{3}, \mathbf{c} \mathrm{SiO}_{2}$ vs. $\mathrm{Na}_{2} \mathrm{O}+\mathrm{K}_{2} \mathrm{O}$, d SiO 2 vs. Mg\#. Rocks shown in the plot include: the silicic clast (dacite; this work); KREEP basalt (Hubbard et al. 1973; Rhodes and Hubbard 1973; Murali et al. 1977; Warren and Wasson 1978; Warren et al. 1978; Salpas et al. 1987; Simon et al. 1988); QMD (Taylor et al. 1980; Lindstrom et al. 1988; Marvin et al. 1991; Ryder and Martinez 1991; Jolliff et al. 1993; Fagan et al. 2014); granite/felsite (Quick et al. 1977; Warren et al. 1983; Morris et al. 1990; Jolliff et al. 1991; Snyder et al. 1992; Seddio et al. 2013); granitic breccia (Morris et al. 1990); terrestrial ferroan (TF) andesite/dacite (Shimazu et al. 1985; Gust and Arculus 1986; Imai et al. 1995; Togashi et al. 2000; Sensarma and Palme 2013)

merrillite in Apollo felsite 14161,7269, and likewise, Warren et al. (1983) identified apatite without merrillite in the granitic sample 14303,204. Factors controlling apatite vs. merrillite are in all likelihood connected to the relative abundances of volatile elements, which are concentrated in apatite, and of rare earth elements, which are concentrated in merrillite. Thus, the dacite clast, like other apatite-rich/merrillite-poor felsic rocks, probably formed in setting that was relatively volatile-rich on the Moon.

Another possible factor in the origin of the dacite is silicate liquid immiscibility (SLI). Immiscibility has been discussed as a possible explanation for the formation of lunar granites and the absence of intermediate lithologies (e.g., Jolliff 1991; Seddio et al. 2013). The occurrence of SLI has been found as micro-scale inclusions in a variety of lunar samples (e.g., Roedder and Weiblen 1970; Shearer et al. 2001) in addition to the evidence from the NWA 773 clan described above. SLI might have played a role in the origin of the dacite clast.
However, no direct textural evidence of SLI has been identified in the dacite. The dacite clast is isolated in breccia: there are no spatial or zoning relationships that show a genetic relationship with lithologies of the NWA 773 clan OG magmatic system. On the other hand, the possibility that the dacite might have formed by immiscibility of other magmatic system involving large-scale gravity separation of silica-rich melt from a parent melt remains plausible in view of the fact that the dacite composition plots on the edge of the miscibility gap of Roedder (1951) (see Appendix). The partitioning of $\mathrm{Ba}$ between Fe-rich and Si-alkali-rich immiscible liquids depends on the molar $\left(\mathrm{Na}_{2} \mathrm{O}+\mathrm{K}_{2} \mathrm{O}+\mathrm{CaO}+\mathrm{BaO}\right) / \mathrm{Al}_{2} \mathrm{O}_{3}$ ratio in the granitic immiscible melt. If the ratio is below 1 , $\mathrm{Ba}$ is partitioned into the granitic melt and if the ratio is over $1, \mathrm{Ba}$ is partitioned into the basic melt (Neal and Taylor 1989). The "alkali" $/ \mathrm{Al}_{2} \mathrm{O}_{3}$ ratio of the dacite clast (1.5) is over 1 , and the value is within the range of "alkali" $/ \mathrm{Al}_{2} \mathrm{O}_{3}$ values of most lunar granites/felsites (1.0-1.7 from Warren et al. 
1983; Neal and Taylor 1989; Morris et al. 1990; Snyder et al. 1992; Seddio et al. 2013; except for 73255c, 0.84 from Warren et al. 1983). The presence of $\mathrm{BaO}$ in zoned alkali feldspar of the dacite clast shows that some $\mathrm{BaO}$ was present in the igneous melt at the time of crystallization. It is possible that $\mathrm{BaO}$ was rapidly depleted from the melt by alkali feldspar crystallization. A potential immiscible pair of the dacite clast has not been identified, so partitioning of $\mathrm{BaO}$ between immiscible liquids cannot be assessed in detail. However, similar values of "alkalis" $/ \mathrm{Al}_{2} \mathrm{O}_{3}$ of the dacite clast and several granitic samples from the Moon suggest general similarities in compositional evolution of $\mathrm{BaO}$ in lunar felsic rocks.

Previous work (Gullikson et al. 2016) supports the crustal melting model for the production of lunar granite from crustal protoliths by partial melting at temperatures below $1000{ }^{\circ} \mathrm{C}$. This model is consistent with the observation that quartz is the only $\mathrm{SiO}_{2}$ polymorph found in lunar granitic samples (Warren et al. 1983; Ling et al. 2011). However, this low-temperature crystallization model does not fit the dacite clast from NWA 2727 because the higher-temperature silica polymorphs cristobalite and tridymite occur along with quartz in the dacite.

The presence of a silica-rich feldspathic glass in the lunar meteorite Yamato 983885 (Y-983885) also requires silica-enrichment followed by rapid cooling (Arai et al. 2005). According to the model of Arai et al. (2005), the $\mathrm{Si}, \mathrm{Al}, \mathrm{K}$-rich glass was derived from rapid cooling of an immiscible felsic liquid that separated from parent liquid before the crystallization of silica (Arai et al. 2005). The glass in Y-983885 apparently represents a case of silicaenrichment followed by rapid cooling distinct from the origin of the dacite clast in NWA 2727. No glass was identified in the dacite clast, suggesting that it cooled more slowly than the Y-983885 glass, but still fast enough to preserve the three low-pressure silica polymorphs.

The high Fe\# ${ }_{99-100}$ of mafic silicates in dacite clast can be explained by crystallization from residual liquid after $\mathrm{Mg}$-depletion by fractional crystallization. The Apollo granite (12032,366-19) studied by Seddio et al. (2013) has a ferroan composition with fayalite and hedenbergite similar to the dacite clast and is interpreted as a product of extended fractional crystallization. Thus, it also has a ferroan composition like the dacite. The coexistence of multiple polymorphs of silica in the NWA 2727 dacite clast distinguishes the dacite from the Apollo 12032,366-19 granite, though the quartz in the Apollo 12 granite has a hackle pattern suggestive of contraction after crystallization and may have recrystallized from a higher-temperature silica polymorph (Seddio et al. 2013, 2015).

Calzada-Diaz et al. (2015) investigated the launch site of the NWA 773 using bulk composition, lunar global element maps $\left(\mathrm{FeO}, \mathrm{TiO}_{2}\right.$, and $\left.\mathrm{Th}\right)$, and age constraints. They suggested that Mare Serenitatis, Crisium, or the west side of Oceanus Procellarum are plausible candidates of the launch site of NWA 773. Most proposed sites of silicic volcanism identified by remote sensing occur in the PKT, located on lunar nearside (Glotch et al. 2010). The presence of the dacite clast is, thus, consistent with a PKT origin for meteorites of the NWA 773 clan, as are the mafic composition, geochemical KREEP signature, and young crystallization age. Thus, among the possibilities discussed by Calzada-Diaz et al. (2015), we prefer the Procellarum and Serenitatis launch sites, as Crisium is farther from the PKT (also see Jolliff et al. 2003). In future work, we will investigate the launch site of NWA 773 clan by comparing the geochemical and petrological data with imaging data with higher spatial resolution.

\section{Conclusions}

NWA 773 clan of lunar meteorites includes a diversity of lithologies: olivine gabbro, anorthositic gabbro, ferroan gabbro (pyroxene gabbro, ferroan symplectite, alkaline-phase ferroan (FG/ARFe)), olivine- and pyroxene-phyric basalts, and, as shown in this study, at least one clast of a silicic lithology. Based on its petrological and geochemical composition, the silicic clast is a dacite. The dacite clast has silica polymorphs of cristobalite, tridymite, and quartz, indicating rapid cooling history of a silicic magma at or near the surface of the Moon. The high silica content, high Fe\# and Ti\# of pyroxene in the clast are consistent with formation at late-stages of magmatic differentiation. Its highly ferroan $(\mathrm{Mg} \#<1)$ and intermediate $\mathrm{SiO}_{2}$ composition (63 wt\%) distinguish the dacite clast from other evolved lunar rocks.

The dacite clast differs from the NWA 773 clan FG/ARFe clasts in the following: (1) plagioclase is more abundant than K-feldspar; (2) only apatite has been identified in the dacite clast, whereas the main Ca-phosphate in the ARFe lithology is merrillite; (3) feldspars and silica are much more abundant than mafic minerals in the dacite clast. The NWA 773 FG/ ARFe clasts formed in a co-magmatic system that also produced the OG and AG lithologies, pyroxene gabbro, and symplectite. The FG/ARFe clasts have curved inclusions of silica-rich feldspathic glass and/or silica $+\mathrm{K}$-feldspar intergrowths. Both types of inclusions in the FG/ARFe clasts formed by silicate liquid immiscibility after Fe-enrichment. However, the dacite clast shows no direct textural evidence of immiscibility associated with the OG magmatic system. The highly ferroan and silica-rich composition of dacite clast formed at least in part by crystallization from residual liquid after Mg-depletion by fractional crystallization of a parental melt. It is possible that immiscibility followed fractional crystallization. The presence of the dacite clast, taken together with mafic composition, geochemical KREEPrich signature and young crystallization age, suggest an origin in or around PKT for meteorites of the NWA 773 clan. 


\section{Appendix}

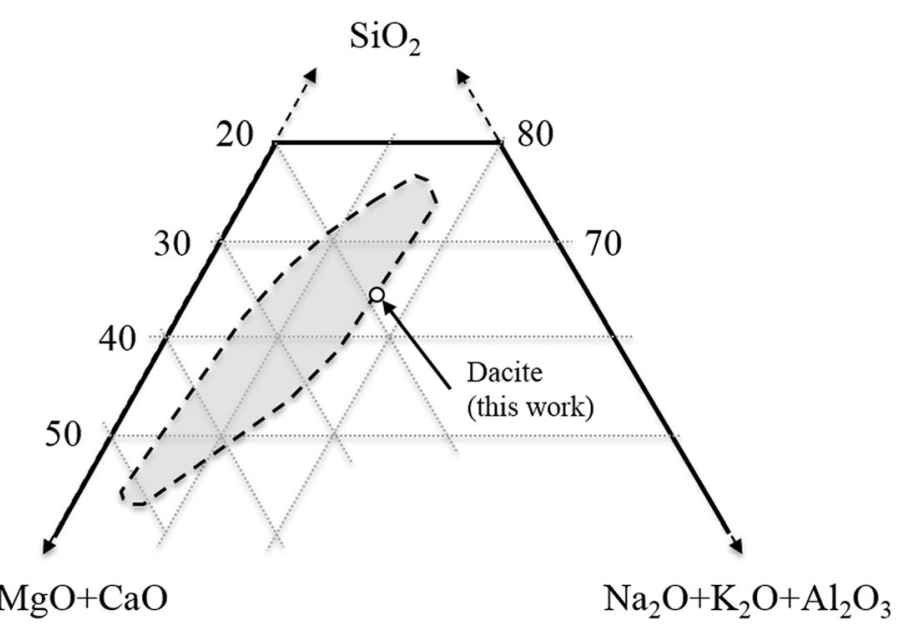

Fig. 10 Ternary diagram among $\mathrm{SiO}_{2}, \mathrm{FeO}+\mathrm{MgO}+\mathrm{CaO}, \mathrm{Na}_{2} \mathrm{O}+\mathrm{K}_{2} \mathrm{O}+\mathrm{Al}_{2} \mathrm{O}_{3}$ (Seddio et al. 2013). Black dotted line encloses the field of $\mathrm{SLI}$ (Roedder 1951). White circle plot represents the dacite clast (this work)

\section{Abbreviations}

ARFe: Alkaline Ferroan; BSE: Back-Scattered Electron; EPMA: Electron probe micro-analyzer; KREEP: Potassium (K); OC: Olivine cumulate gabbro; P: Phosphorus; PKT: Procellarum KREEP Terrane; PTS: Polished thin section; QMD: Quartz monzodiorite; REE: Rare earth element; RGB: Red, Green, Blue; SEM: Scanning electron microscope; SLI: Silicate liquid immiscibility; TAS: Total alkali-silica

\section{Acknowledgments}

We are grateful for loans of thin section from NASA/JSC (R.A. Zeigler, curator) for Apollo 15405 QMD. We acknowledge the helpful comments from two anonymous reviewers and editorial handling by Noriko Kita.

\section{Authors' contributions}

HN proposed the topic, conceived and designed the study. HN and TF carried out the SEM and EPMA analyses. MK carried out Raman spectroscopy. $\mathrm{HN}, \mathrm{TF}$, and MK analyzed the data and helped in their interpretation. All authors discussed the manuscript. All authors read and approved the final manuscript.

\section{Funding}

This work was supported in part by Research Fellowships for Young Scientists from the Japan Society for the Promotion of Science (JSPS) 18 J01786 (PI: Hiroshi Nagaoka) and by JSPS KAKENHI Grant Number $18 \mathrm{H} 01298$ (PI: Masahiro Kayama).

\section{Availability of data and materials}

Data sharing not applicable to this article as no datasets were generated or analyzed during the current study. Please contact author for data requests.

\section{Competing interests}

The authors declare that they have no competing interests.

\section{Author details}

${ }^{1}$ Research Institute for Science and Engineering, Waseda University, 3-4-1 Okubo, Shinjuku, Tokyo 169-8555, Japan. ${ }^{2}$ Institute of Space and Astronautical Science, Japan Aerospace Exploration Agency, 3-1-1 Yoshinodai, Chuo-ku, Sagamihara 252-5210, Japan. ${ }^{3}$ Department of Earth Science, School of Education, Waseda University, 1-6-1 Nishiwaseda, Shinjuku, Tokyo 169-8050, Japan. ${ }^{4}$ Department of Earth and Planetary Materials Science, Graduate School of Science, Tohoku University, Aramaki aza Aoba 6-3, Aoba-ku, Sendai 980-8578, Japan. ${ }^{5}$ Creative Interdisciplinary Research
Division, Frontier Research Institute for Interdisciplinary Sciences, Tohoku University, Aramaki aza Aoba 6-3, Aoba-ku, Sendai 980-8578, Japan. ${ }^{6}$ Department of General Systems Studies, Graduate School of Arts and Sciences, The University of Tokyo, 3-8-1 Komaba, Meguro-ku, Tokyo 153-8902, Japan. 7 JAXA Space Exploration Center, Japan Aerospace Exploration Agency, 3-1-1 Yoshinodai, Chuo-ku, Sagamihara 252-5210, Japan. ${ }^{8}$ School Advanced Science and Engineering, Waseda University, 3-4-1 Okubo, Shinjuku, Tokyo 169-8555, Japan.

Received: 2 July 2019 Accepted: 5 February 2020

Published online: 02 March 2020

\section{References}

Arai T, Otsuki M, Ishii T, Mikouchi T, Miyamoto M (2005) Mineralogy of Yamato 983885 lunar polymict breccia with a KREEP basalt, a high-Al basalt, a very low-Ti basalt and Mg-rich rocks. Antact Meteorite Res 18:17-45

Barboni M, Boehnke P, Keller B, Kohl IE, Schoene B, Young ED, McKeegan KD (2017) Early formation of the Moon 4.51 billion years ago. Sci Adv 3: e1602365

Barrat J-A, Yamaguchi A, Greenwood RC, Bollinger C, Bohn M, Franchi I-A (2009) Trace element geochemistry of K-rich impact spherules from howardites. Geochim Cosmochim Acta 73:5944-5958

Baxter PJ, Bonadonna C, Dupree R, Hards VL, Kohn SC, Murphy MD, Nichols A, Nicholson RA, Norton G, Searl A, Sparks RSJ, Vickers BP (1999) Cristobalite in volcanic ash of the Soufriere Hills volcano, Montserrat, British West Indies. Science 283:1142-1145

Bence AE, Papike JJ, Prewitt CT (1970) Apollo 12 clinopyroxene: chemical trends. Earth Planet Sci Lett 8:393-399

Bischoff A, Horstmann M, Barrat J-A, Chaussidon M, Pack A, Herwartz D, Ward C, Vollmer C, Decker S (2014) Trachyandesitic volcanism in the early solar system. Proc Natl Acad Sci 111:12689-12692

Bonin B (2012) Extra-terrestrial igneous granites and related rocks: a review of their occurrence and petrogenesis. Lithos 153:3-24

Borg LE, Connelly JN, Boyet M, Carlson RW (2011) Chronological evidence that the Moon is either young or did not have a global magma ocean. Nature 477:70-72

Borg LE, Gaffney AM, Shearer CK, DePaolo DJ, Hutcheon ID, Owens TL, Ramon E, Brennecka G (2009) Mechanisms for incompatible-element enrichment on the Moon deduced from the lunar basaltic meteorite Northwest Africa 032 Geochim Cosmochim Acta 73:3963-3980

Brown M (2013) Granite: from genesis to emplacement. Geol Soc Am Bull 125: $1079-1113$ 
Bunch TE, Wittke JH, Korotev RL, Irving AJ (2006) Lunar meteorites NWA 2700 NWA 2727 and NWA 2977: Mare basalts/gabbro breccias with affinities to NWA 773. In: Abstracts of the 37th lunar and planetary science conference, 2006, League city, Texas, p 1375

Calzada-Diaz A, Joy KH, Crawford IA, Nordheim TA (2015) Constraining the source regions of lunar meteorites using orbital geochemical data. Meteorit Planet Sci 50:214-228

Campbell IH, Taylor SR (1983) No water, no granites-no oceans, no continents. Geophys Res Lett 10:1061-1064

Connolly HC, Zipfel J, Grossman JN, Folco L, Smith C, Jones RH, Righter K, Zolensky M, Russell SS, Benedix GK, Yamaguchi A, Cohen BA (2006) The Meteoritical Bulletin, No. 90, 2006 September. Meteorit Planet Sci 41: 1383-1418

Day JMD, Ash RD, Liu Y, Bellucci JJ, Rumble D III, McDonough WF, Walker RJ, Taylor LA (2009) Early formation of evolved asteroidal crust. Nature 457:179-182

Elardo SM, Shearer CK Jr, Fagan AL, Borg LE, Gaffney AM, Burger PV, Neal CR, Fernandes VA, McCubbin FM (2014) The origin of young mare basalts inferred from lunar meteorites Northwest Africa 4734, 032, and LaPaz Icefield 02205. Meteorit Planet Sci 49:261-291

Etchepare J, Merian M, Smetankine L (1974) Vibrational normal modes of SiO2. I. $\alpha$ and $\beta$ quartz. J Chem Phys 60:1873. https://doi.org/10.1063/1.1681287

Fagan TJ, Kashima D, Wakabayashi Y, Suginohara A (2014) Case study of magmatic differentiation trends on the Moon based on lunar meteorite Northwest Africa 773 and comparison with Apollo 15 quartz monzodiorite. Geochim Cosmochim Acta 133:97-127

Fagan TJ, Taylor GJ, Keil K, Hicks TL, Killgore M, Bunch TE, Wittke JH, Mittlefehldt DW, Clayton RN, Mayeda TK, Eugster O, Lorenzetti S, Norman MD (2003) Northwest Africa 773: lunar origin and iron-enrichment trend. Meteorit Planet Sci 38:529-554

Frost CD, Frost BR (2011) On ferroan (A-type) granitoids: their compositional variability and modes of origin. J Petrol 52:39-53

Glotch TD, Lucey PG, Bandfield JL, Greenhagen BT, Thomas IR, Elphic RC, Bowles N, Wyatt MB, Allen CC, Hanna KD, Paige DA (2010) Highly silicic compositions on the Moon. Science 329:1510-1513. https://doi.org/10.1126/ science. 1192148

Grove TL, Krawczynski MJ (2009) Lunar mare volcanism: where did the magmas come from? Elements 5:29-34

Gullikson AL, Hagerty J, Reid MR, Rapp JF, Draper D (2016) Silicic lunar volcanism: testing the crustal melting model. Am Mineral 101:2312-2321

Gust DA, Arculus RJ (1986) Petrogenesis of alkalic and calcalkalic volcanic rocks of Mormon Mountain volcanic field, Arizona. Contrib Mineral Petrol 94:416-426

Hagerty JJ, Lawrence DJ, Hawke BR, Vaniman DT, Elphic RC, Feldman WC (2006) Refined thorium abundances for lunar red spots: implications for evolved, nonmare volcanism on the Moon. J Geophys Res 111:E06002

Hahn TM Jr, Lunning NG, McSween HY Jr, Bodnar RJ, Taylor LA (2017) Dacite formation on Vesta: partial melting of the eucritic crust. Meterorit Planet Sci 52:1173-1196

Hamasaki S (2002) Volcanic-related alteration and geochemistry of Iwodake volcano, Satsuma-Iwojima, Kyusyu, SW Japan. Earth Planet Space 54:217-229

Hawke BR, Lawrence DJ, Blewett DT, Lucey PG, Smith GA, Spudis PD, Taylor GJ (2003) Hansteen alpha: a volcanic construct in the lunar highlands. J Geophys Res Planet 108:5069

Head JW, McCord TB (1978) Imbrian-age highland volcanism on the moon-the Gruithuisen and Mairan domes. Science 199:1433-1436

Hiesinger H, Head JW III, Wolf U, Jaumann R, Neukum G (2003) Ages and stratigraphy of mare basalts in Oceanus Procellarum, Mare Nubium, Mare Cognitum, and Mare Insularum. J Geophys Res 108:5065

Hiesinger $\mathrm{H}$, Head JW, Wolf U, Jaumann R, Neukum G (2010) Ages and stratigraphy of lunar mare basalts in Mare Frigoris and other nearside maria based on crater size-frequency distribution measurements. J Geophys Res 115:E03003

Holland TJB, Powell R (2011) An improved and extended internally consistent thermodynamic dataset for phases of petrological interest, involving a new equation of state for solids. J Metamorph Geol 29:333-383

Horwell CJ, Le Blond JS, Michnowicz SAK, Cressey G (2010) Cristobalite in a rhyolitic lava dome: evolution of ash hazard. Bull Volcanol 72:249-253

Hubbard NJ, Rhodes JM, Gast PW, Bansal BM, Shih C-Y, Wiseman H, Nyquist LE (1973) Lunar rock types: the role of plagioclase in non-mare and highland rock types. In: Proceedings of the 4th lunar science conference, 1973, Houston, Texas, pp 1297-1312
Imai N, Terashima S, Itoh S, Ando A (1995) 1994 compilation values for GSJ reference samples, "Igneous rock series" (letter). Geochem J 29:91-95

Jolliff BJ, Zeigler RA, Korotev RL (2007) Compositional characteristics and petrogenetic relationships among the NWA 773 clan of lunar meteorites. In: Abstracts of the 38th lunar and planetary science conference, 2007, League City, Texas, p 1489

Jolliff BL (1991) Fragments of quartz monzodiorite and felsite in Apollo 14 soil partilces. In: Proceedings of the 21st lunar and planetary science conference, 1990, Houston, Texas, pp 101-118

Jolliff BL, Floss C, McCallum IS, Schwartz JM (1999) Geochemistry, petrology, and cooling history of 14161,7373: a plutonic lunar sample with textural evidence of granitic-fraction separation by silicate liquid immiscibility. Am Mineral 84: $821-837$

Jolliff BL, Gillis JJ, Haskin LA, Korotev RL, Wieczorek MA (2000) Major lunar crustal terranes: surface expressions and crust-mantle origins. J Geophys Res 105: 4197-4216

Jolliff BL, Haskin LA, Colson RO, Wadhwa M (1993) Partitioning in REE-saturating minerals: theory, experiment, and modelling of whitlockite, apatite, and evolution of lunar residual magmas. Geochim Cosmochim Acta 57:4069-4094

Jolliff BL, Korotev RL, Haskin LA (1991) Geochemistry of 2-4 mm particles from Apollo 14 soil (14161) and implications regarding igneous components and soil-forming processes. In: Proceedings of the 21st lunar and planetary science conference, 1990, Houston, Texas, pp 193-219

Jolliff BL, Korotev RL, Zeigler RA, Floss C (2003) Northwest Africa 773: lunar mare breccia with a shallow-formed olivine-cumulate component, inferred verylow-Ti (VLT) heritage, and a KREEP connection. Geochim Cosmochim Acta 67:4857-4879

Kayama M, Tomioka N, Ohtani E, Seto Y, Nagaoka H, Götze J, Miyake A, Ozawa S, Sekine T, Miyahara M, Tomeoka K, Matumoto M, Shoda N, Hirao N, Kobayashi $\mathrm{T}$ (2018) Discovery of moganite in a lunar meteorite as a trace of $\mathrm{H}_{2} \mathrm{O}$ ice in the Moon's regolith. Sci Adv 4:eaar4378

Koike C, Noguchi R, Chihara H, Suto H, Ohtaka O, Imai Y, Matsumoto T, Tsuchiyama A (2013) Infrared spectra of silica polymorphs and the conditions of their formation. Astrophys J 778:60. https://doi.org/10.1088/0004-637X/778/1/60

Le Bas MJ, Le Maitre RW, Woolley AR (1992) The construction of the total alkalisilica chemical classification of volcanic rocks. Mineral Petrol 46:1-22

Lindstrom MM, Marvin UB, Vetter SK, Shervais JW (1988) Apennine front revisited: diversity of Apollo 15 highland rock types. In: Proceedings of the 18th lunar and planetary science conference, 1987, Houston, Texas, pp 169-185

Ling ZC, Wang A, Jolliff BL (2011) Mineralogy and geochemistry of four lunar soils by laser-Raman study. Icarus 211:101-113

Marvin UB, Lindstrom MM, Holmberg BB, Martinez RR (1991) New observations on the quartz monzodiorite-granite suite. In: Proceedings of the 21 st lunar and planetary science conference, 1990, Houston, Texas, pp 119-135

Morota T, Haruyama J, Ohtake M, Matsunaga T, Honda C, Yokota Y, Kimura J, Ogawa Y, Demura H, Iwasaki A, Sugihara T, Saiki K, Nakamura R, Kobayashi S, Ishihara Y, Takeda H, Hiesinger H (2011) Timing and characteristics of the latest mare eruption on the Moon. Earth Planet Sci Lett 302:255-266

Morris RV, Vaniman DT, Blake DF, Gellert R, Chipera SJ, Rampe EB, Ming DW, Morrison SM, Downs RT, Treiman AH, Yen AS, Grotzinger JP, Achilles CN, Bristow TF, Crisp JA, Des Marais DJ, Farmer JD, Frendrich KV, Frydenvang J, Graff TG, Morookian J-M, Stolper EM, Schwenzer SP (2016) Silicic volcanism on Mars evidenced by tridymite in high- $\mathrm{SiO}_{2}$ sedimentary rock at Gale crater. Proc Natl Acad Sci 113:7071-7076

Morris RW, Taylor GJ, Newsom HE, Keil K, Garcia SR (1990) Highly evolved and ultramafic lithologies from Apollo 14 soils. In: Proceedings of the 20th lunar and planetary science conference, 1990, Houston, Texas, pp 61-75

Murali AV, Ma M-S, Laul JC, Schmitt RM (1977) Chemical composition of breccias, feldspathic basalt, and anorthosites from Apollo 15 (15308, 15359, 15382, and 15362), Apollo 16 (60018 and 65785), Apollo 17 $(72435,72536,72559,72735,72738,78526$, and 78527), and Luna 20 (22012 and 22013). In: Abstracts of the 8th lunar science conference, 1977, Houston, Texas, pp 700-702

Nagaoka H, Fagan TJ, Kayama M, Karouji Y, Hasebe N, Ebihara M (2019) Mineralogic and petrologic characterization of a new silicic clast in lunar brecciated meteorite, Northwest Africa 2727. In: Abstracts of the 50th lunar and planetary science conference, 2019, the Woodlands, Texas, p 2270

Nagaoka H, Karouji Y, Takeda H, Fagan TJ, Ebihara M, Hasebe N (2015) Mineralogy and petrology of lunar meteorite Northwest Africa 2977 consisting of olivine cumulate gabbro including inverted pigeonite. Earth Planet Space 67:200. https://doi.org/10.1186/s40623-015-0368-y 
Neal CR, Taylor LA (1989) The nature of barium partitioning between immiscible melts: a comparison of experimental and natural systems with reference to lunar granite petrogenesis. In: Proceedings of the 19th lunar and planetary science conference, 1989, Houston, Texas, pp 209-218

Nyquist LE, Shih C-Y (1992) The isotopic record of lunar volcanism. Geochim Cosmochim Acta 56:2213-2234

Nyquist LE, Shish C-Y, Reese YD, Irving AJ (2009) Sm-Nd and Rb-Sr ages for Northwest Africa 2977, a young lunar gabbro from the PKT. In Abstracts of the 72nd annual meeting of the Meteoritical society, Nancy, 2009, p 5347. Meteorit Planet Sci 44(S7):A15-A229

Papike J, Taylor L, Simon S (1991) Lunar minerals. In: Heiken GH, Vaniman DT, French BM (eds) Lunar source book. Cambridge Univ Press, New York, pp 121-181

Presnall DC (1995) Phase diagrams of earth-forming minerals. In: Ahrens TJ (ed) Mineral Physics \& Crystallography, a handbook of physical constants, vol 2. American Geophysical Union, Washington, DC, pp 248-268

Quick JE, Albee AL, Ma M-S, Murali AV, Schmitt RA (1977) Chemical composition and possible immiscibility of two silicate melts in 12013. In: Proceedings of the 8th lunar science conference, 1977, Houston, Texas, pp 2153-2189

Rhodes JM, Hubbard NJ (1973) Chemistry, classification, and petrogenesis of Apollo 15 mare basalts. In: Proceedings of the 4th lunar science conference, 1973, Houston, Texas, pp 1127-1148

Roedder $\mathrm{E}$ (1951) Low temperature liquid immiscibility in the system $\mathrm{K}_{2} \mathrm{O}-\mathrm{FeO}$ $\mathrm{Al}_{2} \mathrm{O}_{3}-\mathrm{SiO}_{2}$. Am Mineral 36:282-286

Roedder E, Weiblen PW (1970) Lunar petrology of silicate melt inclusions, Apollo 11 rocks. Geochim Cosmochim Acta Suppl 1:801-837

Rutherford MJ, Hess PC, Daniel GH (1974) Experimental liquid line of descent and liquid immiscibility for basalt 70017. In: Proceedings of the 5th lunar science conference, 1974, Houston, Texas, pp 569-583

Rutherford MJ, Hess PC, Ryerson FJ, Campbell HW, Dick PA (1976) The chemistry, origin and petrogenetic implications of lunar granite and monzonite. In: Proceedings of the 7th lunar science conference, 1976, Houston, Texas, pp $1723-1740$

Ryder G, Martinez RR (1991) Evolved hypabyssal rocks from station 7, Apennine front, Apollo 15. In: Proceedings of the 21st lunar and planetary science conference, 1990, Houston, Texas, pp 137-150

Salpas PA, Taylor LA, Lindstrom MM (1987) Apollo 17 KREEPy basalts: Evidence for the non-uniformity of KREEP. In: Proceedings of the 17th Lunar and Planetary Science Conference, 1986, Houston, Texas. J Geophys Res 92:E340-E348

Seddio SM, Jolliff BL, Korotev RL, Carpenter PK (2014) Thorite in an Apollo 12 granite fragment and age determination using the electron microprobe. Geochim Cosmochim Acta 135:307-320

Seddio SM, Jolliff BL, Korotev RL, Zeigler RA (2013) Petrology and geochemistry of lunar granite 12032,366-19 and implications for lunar granite petrogenesis. Am Mineral 98:1697-1713

Seddio SM, Korotev RL, Jolliff BL, Wang A (2015) Silica polymorphs in lunar granite: implications for granite petrogenesis on the Moon. Am Mineral 100: 1533-1543

Sensarma S, Palme H (2013) Silicate liquid immiscibility in the 2.5 Ga Fe-rich andesite at the top of Dongargarh large igneous province (India). Lithos 170171:239-251

Shaulis BJ, Righter M, Lapen TJ, Jolliff BJ, Irving AJ (2017) 3.1 Ga crystallization age for magnesian and ferroan gabbro lithologies in the Northwest Africa 773 clan of lunar meteorites. Geochim Cosmochim Acta 213:435-456

Shearer CK, Papike JJ, Spilde MN (2001) Trace-element partitioning between immiscible lunar melts: an example from naturally occurring lunar melt inclusions. Am Mineral 86:238-246

Shimazu M, Igarashi S, Ohashi M (1985) Tholeiitic andesite and dacite of early Pleistocene age in Shikumi area, Niigata prefecture, Japan. J Japan Assoc Min Petr Econ Geol 80:119-127

Simon SB, Papike JJ, Laul JC (1988) Chemistry and petrology of the Apennine front, Apollo 15, part I: KREEP basalts and plutonic rocks. In: Proceedings of the 18th lunar and planetary science conference, 1987, Houston, Texas, pp 187-201

Snape JF, Nemchin AA, Bellucci JJ, Whitehouse MJ, Tartèse R, Barnes JJ, Anand M, Crawford IA, Joy KH (2016) Lunar basalt chronology, mantle differentiation and implications for determining the age of the Moon. Earth Planet Sci Lett 451:149-158

Snyder GA, Taylor LA, Liu Y-G, Schmitt RA (1992) Petrogenesis of the western highlands of the Moon: evidence from a diverse group of whitlockite-rich rocks from the Fra Mauro formation. In: Proceedings of the 22nd Lunar and Planetary Science Conference, 1991, Houston, Texas, pp 399-416
Srinivasan P, Dunlap DR, Agee CB, Wadhwa M, Coleff D, Ziegler K, Zeigler R, McCubbin FM (2018) Silica-rich volcanism in the early solar system dated at 4.565 Ga. Nat Commun 9:3036

Streckeisen A (1979) Classification and nomenclature of volcanic rocks, lampro phyres, carbonatites, and melilitic rocks: recommendations and suggestions of the IUGS subcommission on the systematics of igneous rocks. Geology 7: 331-335

Takeda H (1986) Mineralogy of Yamato 791073 with reference to crystal fractionation of the howardite parent body. In: Proceedings of the 16th Lunar and Planetary Science Conference, 1985, Houston, Texas. J Geophys Res 91:D355-D363

Takeda H, Nagaoka H, Yamaguchi A, Karouji Y, Yazawa Y (2015) Mineralogy of some evolved LL chondrites with reference to asteroid materials and solar system evolution. Earth Planet Space 67:5. https://doi.org/10.1186/s40623014-0167-x

Tatsumi Y (2000) Continental crust formation by crustal delamination in subduction zones and complementary accumulation of the enriched mantle I component in the mantle. Geochem Geophys Geosyst 1:2000GC000094

Taylor GJ, Warner RD, Keil K, Ma M-S, Schmitt RA (1980) Silicate liquid immiscibility, evolved lunar rocks and the formation of KREEP. In: Proceedings of the conference on the lunar highlands crust, 1979, Houston, Texas, pp 339-352

Togashi S, Imai N, Okuyama-Kusunose Y, Tanaka T, Okai T, Koma T, Murata Y (2000) Young upper crustal chemical composition of the orogenic Japan Arc. Geochem Geophys Geosyst 1:2000GC000083

Valencia SN, Jolliff BL, Korotev RL (2019) Petrography, relationships, and petrogenesis of the gabbroic lithologies in Northwest Africa 773 clan members Northwest Africa 773, 2727, 3160, 3170, 7007, and 10656. Meteorit Planet Sci 54:2083-2115

Warren PH (1985) The magma ocean concept and lunar evolution. Annu Rev Earth Planet Sci 13:201-240

Warren PH, Afiattalab F, Wasson JT (1978) Investigation of unusual KREEPy samples: pristine rock 15386, cone crater soil fragments 14143, and 12023, a typical Apollo 12 soil. In: Proceedings of the 9th lunar and planetary science conference, 1978, Houston, Texas, pp 653-660

Warren PH, Taylor GJ, Keil K, Shirley DN, Wasson JT (1983) Petrology and chemistry of two "large" granite clasts from the Moon. Earth Planet Sci Lett 64:175-185

Warren PH, Wasson JT (1978) Compositional-petrographic investigation of pristine nonmare rocks. In: Proceedings of the 9th lunar and planetary science conference, 1978, Houston, Texas, pp 185-217

Weinberg RF, Hasalová P (2015) Water-fluxed melting of the continental crust: a review. Lithos 212-215:158-188

Wieczorek MA, Jolliff BL, Khan A, Pritchard ME, Weiss BP, Williams JG, Hood LL, Righter K, Neal CR, Shearer CK, McCallum IS, Tompkins S, Hawke BR, Peterson C, Gillis JJ, Bussey B (2006) The constitution and structure of the lunar interior. In: Jolliff BL, Wieczorek MA, Shearer CK, Neal CR (eds) New views of the moon, reviews in mineralogy \& geochemistry, vol 60. Mineralogical Society America Press, Virginia, pp 221-364

Zeigler RA, Korotev RL, Jolliff BL (2007) Petrography, geochemistry, and pairing relationships of basaltic lunar meteorite stones. In: Abstracts of the 38th lunar and planetary science conference, 2007, Houston, Texas, p 2109

Zhang A-C, Hsu W-B, Floss C, Li X-H, Li Q-L, Liu Y, Taylor LA (2011) Petrogenesis of lunar meteorite Northwest Africa 2977: constraints from in situ microprobe results. Meteorit Planet Sci 45:1929-1947

\section{Publisher's Note}

Springer Nature remains neutral with regard to jurisdictional claims in published maps and institutional affiliations. 